\title{
Review
}

\section{Differences in MPS I and MPS II Disease Manifestations}

\author{
Christiane S. Hampe ${ }^{1, *}$, Brianna D. Yund ${ }^{2}$, Paul J. Orchard ${ }^{2}$ (D) Troy C. Lund ${ }^{2}$, Jacob Wesley ${ }^{1}$ and \\ R. Scott McIvor ${ }^{3,4}$ \\ 1 Immusoft Corp., Seattle, WA 98103, USA; jake.wesley@immusoft.com \\ 2 Department of Pediatrics, University of Minnesota, Minneapolis, MN 55455, USA; bdy@umn.edu (B.D.Y.); \\ orcha001@umn.edu (P.J.O.); lundx072@umn.edu (T.C.L.) \\ 3 Immusoft Corp., Minneapolis, MN 55413, USA; r.scott.mcivor@immusoft.com or mcivo001@umn.edu \\ 4 Department of Genetics, Cell Biology and Development and Center for Genome Engineering, University of \\ Minnesota, Minneapolis, MN 55413, USA \\ * Correspondence: chris.hampe@immusoft.com; Tel.: +1-206-554-9181
}

check for

updates

Citation: Hampe, C.S.; Yund, B.D.; Orchard, P.J.; Lund, T.C.; Wesley, J.; McIvor, R.S. Differences in MPS I and MPS II Disease Manifestations. Int. J. Mol. Sci. 2021, 22, 7888. https:// doi.org/10.3390/ijms22157888

Academic Editors: Shunji Tomatsu, Grzegorz Wegrzyn,

Roberto Giugliani, Brian Bigger and Julia B. Hennermann

Received: 30 June 2021

Accepted: 16 July 2021

Published: 23 July 2021

Publisher's Note: MDPI stays neutral with regard to jurisdictional claims in published maps and institutional affiliations.

Copyright: (C) 2021 by the authors Licensee MDPI, Basel, Switzerland. This article is an open access article distributed under the terms and conditions of the Creative Commons Attribution (CC BY) license (https:/ / creativecommons.org/licenses/by/ $4.0 /)$.

\begin{abstract}
Mucopolysaccharidosis (MPS) type I and II are two closely related lysosomal storage diseases associated with disrupted glycosaminoglycan catabolism. In MPS II, the first step of degradation of heparan sulfate (HS) and dermatan sulfate (DS) is blocked by a deficiency in the lysosomal enzyme iduronate 2-sulfatase (IDS), while, in MPS I, blockage of the second step is caused by a deficiency in iduronidase (IDUA). The subsequent accumulation of HS and DS causes lysosomal hypertrophy and an increase in the number of lysosomes in cells, and impacts cellular functions, like cell adhesion, endocytosis, intracellular trafficking of different molecules, intracellular ionic balance, and inflammation. Characteristic phenotypical manifestations of both MPS I and II include skeletal disease, reflected in short stature, inguinal and umbilical hernias, hydrocephalus, hearing loss, coarse facial features, protruded abdomen with hepatosplenomegaly, and neurological involvement with varying functional concerns. However, a few manifestations are disease-specific, including corneal clouding in MPS I, epidermal manifestations in MPS II, and differences in the severity and nature of behavioral concerns. These phenotypic differences appear to be related to different ratios between DS and HS, and their sulfation levels. MPS I is characterized by higher DS/HS levels and lower sulfation levels, while HS levels dominate over DS levels in MPS II and sulfation levels are higher. The high presence of DS in the cornea and its involvement in the arrangement of collagen fibrils potentially causes corneal clouding to be prevalent in MPS I, but not in MPS II. The differences in neurological involvement may be due to the increased HS levels in MPS II, because of the involvement of HS in neuronal development. Current treatment options for patients with MPS II are often restricted to enzyme replacement therapy (ERT). While ERT has beneficial effects on respiratory and cardiopulmonary function and extends the lifespan of the patients, it does not significantly affect CNS manifestations, probably because the enzyme cannot pass the blood-brain barrier at sufficient levels. Many experimental therapies, therefore, aim at delivery of IDS to the CNS in an attempt to prevent neurocognitive decline in the patients.
\end{abstract}

Keywords: mucopolysaccharidosis type I; mucopolysaccharidosis type II; glycosaminoglycans; dermatan sulfate; heparin sulfate

\section{Introduction}

Mucopolysaccharidosis type I and II are two of eleven inherited lysosomal storage diseases associated with disrupted glycosaminoglycan catabolism.

Mucopolysaccharidosis type II (MPS II) [1] is a genetic disorder inherited in an Xlinked recessive pattern and affects $\sim 1 / 160,000$ live male births [2]. However, the prevalence of MPS II shows geographical differences, and MPS II is the more common form in East Asia, while MPS I is the more prevalent form in Europa and North America [3]. MPS II is caused by deficiency of the lysosomal enzyme iduronate 2-sulfatase (IDS). IDS 
catalyzes the first step of the degradation of heparan sulfate (HS) and dermatan sulfate (DS). IDS deficiency results in the accumulation of these glycosaminoglycans (GAGs). This causes lysosomal hypertrophy and an increase in the number of lysosomes in cells. GAGs are present throughout the body and are an essential part of the extracellular matrix (ECM). Lack of GAG turnover in the ECM affects cellular functions, like cell adhesion, endocytosis, intracellular trafficking of different molecules, intracellular ionic balance, and inflammation. Despite MPS II being the most variable and wide-ranging of the MPS types, MPS II is often described as either an attenuated or "non-neuronopathic" phenotype, or a severe, progressive, "neuronopathic" phenotype involving central nervous system dysfunction. However, patients with less severe neurocognitive disease may still exhibit severe somatic symptoms, calling the term "attenuated disease" into question [4,5]. Moreover, the disease encumbers a broad spectrum of cognitive and somatic features, so that the distinction into two separate phenotypes may not be accurate $[5,6]$.

Approximately $2 / 3$ of patients with MPS II develop CNS manifestations [7-10], which become evident at $2-4$ years of age [11]. Symptoms progress with age, and death in untreated patients typically occurs by 10-15 years of age [12]. Patients with lack of or mild neurological involvement typically display symptoms at a later age and often survive into their 5th decade [10].

The closely related disease mucopolysaccharidosis type I (MPS I) is caused by deficiency of the lysosomal enzyme iduronidase (IDUA), catalyzing step two in the degradation of HS and DS. In both MPS I and MPS II, HS and DS accumulate and patients share characteristic phenotypical manifestations, including worsening skeletal disease reflected in short stature, inguinal and umbilical hernias, hydrocephalus, hearing loss, coarse facial features, protruded abdomen with hepatosplenomegaly, and neurological involvement with varying functional concerns (Table 1). Manifestations are more prevalent and severe in the most severe form of MPS I (Hurler syndrome or MPS IH), which constitutes $>50 \%$ of MPS I cases $[13,14]$. Overall, manifestations shared by both MPS I and MPS II usually develop earlier in children with severe MPS I as compared to MPS II (Table 2) [11,12,15-18]. A few MPS I and MPS II specific manifestations have been described [19]. In this review, we will discuss these differences and the consequences on treatment options, and we speculate about possible biochemical mechanisms for these differences.

Table 1. Prevalence of clinical manifestations in severe types of MPS II and MPS IH in the absence of therapy.

\begin{tabular}{|c|c|c|c|c|}
\hline Manifestation & $\begin{array}{c}\text { MPS II } \\
\text { (Hunter Syndrome) }\end{array}$ & References & $\begin{array}{c}\text { MPS IH } \\
\text { (Hurler Syndrome) }\end{array}$ & References \\
\hline Umbilical hernia & $70-95 \%$ & {$[12,19]$} & $60-75 \%$ & [19-22] \\
\hline Inguinal hernia & $70-95 \%$ & {$[12,19]$} & $60-75 \%$ & [19-22] \\
\hline Hepatosplenomegaly & $60-90 \%$ & {$[10,12,19,23]$} & $70-85 \%$ & {$[19,20]$} \\
\hline Skeletal manifestations & $80 \%$ & [24] & $80 \%$ & {$[22,25]$} \\
\hline Kyphosis & $34 \%$ & $\begin{array}{c}{[10,12,18,19,23,} \\
24]\end{array}$ & $70-90 \%$ & [26] \\
\hline Odontoid hypoplasia & rare & [10] & $65 \%$ & [27] \\
\hline Joint stiffness & $75-90 \%$ & {$[10,19,23,24]$} & $93 \%$ & {$[19,20,26]$} \\
\hline Poor growth & $79 \%$ & {$[12,19,24]$} & $100 \%$ & {$[19,22,24]$} \\
\hline $\begin{array}{l}\text { Epidermal symptoms } \\
\text { (thickened skin with pebble formation, } \\
\text { persistent Mongolian spots) }\end{array}$ & $13-17 \%$ & {$[19,28-30]$} & rare & \\
\hline Coarse facial features & $95 \%$ & {$[10,23]$} & $86-97 \%$ & [13] \\
\hline Upper respiratory issues & $100 \%$ & {$[12,19]$} & $80-100 \%$ & {$[19,20,22,25]$} \\
\hline
\end{tabular}


Table 1. Cont.

\begin{tabular}{|c|c|c|c|c|}
\hline Manifestation & $\begin{array}{c}\text { MPS II } \\
\text { (Hunter Syndrome) }\end{array}$ & References & $\begin{array}{c}\text { MPS IH } \\
\text { (Hurler Syndrome) }\end{array}$ & References \\
\hline Lower respiratory issues & $80-90 \%$ & {$[12,24]$} & $80-90 \%$ & {$[21,22,31]$} \\
\hline Loss of hearing & $70-95 \%$ & {$[8,12,28,32]$} & $76-100 \%$ & {$[20,25]$} \\
\hline Valvular heart disease & $50-60 \%$ & {$[10,23,28,33,34]$} & $40-100 \%$ & $\begin{array}{c}{[13,20-} \\
22,25,35,36]\end{array}$ \\
\hline Corneal clouding & rare & [19] & $71-88 \%$ & {$[19-22,25]$} \\
\hline Seizures & $60 \%$ & {$[12,37]$} & rare & [38] \\
\hline Cognitive impairment & $100 \%$ & {$[12,23,28]$} & $100 \%$ & {$[22,39,40]$} \\
\hline Behavioral disturbances & $30-45 \%$ & $\begin{array}{c}{[8,12,19,23,28,} \\
41]\end{array}$ & rare & [19] \\
\hline Diarrhea & $60 \%$ & {$[12,19,23,28]$} & rare & [19] \\
\hline
\end{tabular}

\section{Accumulated Glycosaminoglycans}

Since the enzymatic defects in MPS I and MPS II both result in the accumulation of HS and DS, the clinical differences between both diseases cannot be explained by GAG species accumulation alone. However, biochemical analyses of HS and DS levels in urine and tissue samples of patients with MPS I and MPS II suggest distinct differences in the relative HS and DS levels, sulfation pattern, and non-reducing terminus status [42].

\subsection{DS/HS Ratio}

Overall, patients with MPS II present with higher HS levels, while patients with MPS I show higher DS levels [43]. Langereis reported that, even though the levels can vary considerably between patients, the urinary DS/HS ratio in patients with MPS I is consistently above 1, while it is consistently below 1 in patients with MPS II [44]. Other reports confirmed lower DS/HS ratios in patients with MPS II compared with patients with MPS I [45,46]. Significantly higher HS/DS ratios were also observed in MPS II mice [47,48]. Importantly, these urinary DS/HS ratios reflect those in CSF and brain $[47,49]$.

The possible outcomes of the different ratios of HS and DS on the respective pathogenesis are demonstrated in two other MPS types, MPS III and MPS VI. Patients with MPS III show accumulation of HS only and suffer from neurodegeneration, seizures, and diarrhea, while coarse facial features, hepatomegaly, hernias, and dysostosis multiplex are milder in form [50]. Patients with MPS VI accumulate DS only and present with severe dysostosis multiplex, joint stiffness, coarse facial features, and corneal clouding, in the absence of impaired intellectual development [51]]. Consistent with these studies, a correlation between elevated DS levels (relative to HS levels) can be found in patients with MPS with severe viscera and skeletal manifestations [49,52], while elevated HS levels (relative to DS levels) are associated with dysfunction of the CNS [43,52-55]. Indeed, MPS II patients with neurocognitive involvement showed significantly elevated HS levels in their CSF compared with patients without cognitive impairment [56].

\subsection{HS and DS Functions}

HS is a major component of the ECM and plays a critical role in cell signaling, recognition of growth factors, cytokines, morphogens [57,58], and regulation of chemokine and cytokine gradients $[59,60]$. Abnormal HS levels in the CNS lead to dysregulation of neuronal differentiation, growth, and neurotransmission [42,61,62], which may, in part, explain the higher prevalence of neurocognitive involvement in patients with MPS II.

DS is found in skin, bones, connective tissues, and cartilage, with biological functions including binding of growth factors, cytokines, and chemokines [63]. Its role in skeletal growth and development of the cornea has been illustrated in rats treated with the antiviral drug Tilorone. Tilorone treatment is accompanied by accumulation of DS, with only minor 
HS accumulation $[64,65]$. The treated rats develop bone alterations and corneal clouding similar to those seen in MPS I [66,67].

\subsection{Sulfation Levels}

Apart from different DS/HS ratios, MPS I and MPS II present different degradation products of both GAGs [68]. These differences stem from the position of IDS and IDUA in the GAG degradation pathway, respectively (Figure 1).

\section{Heparan sulphate}

\section{Dermatan sulphate}

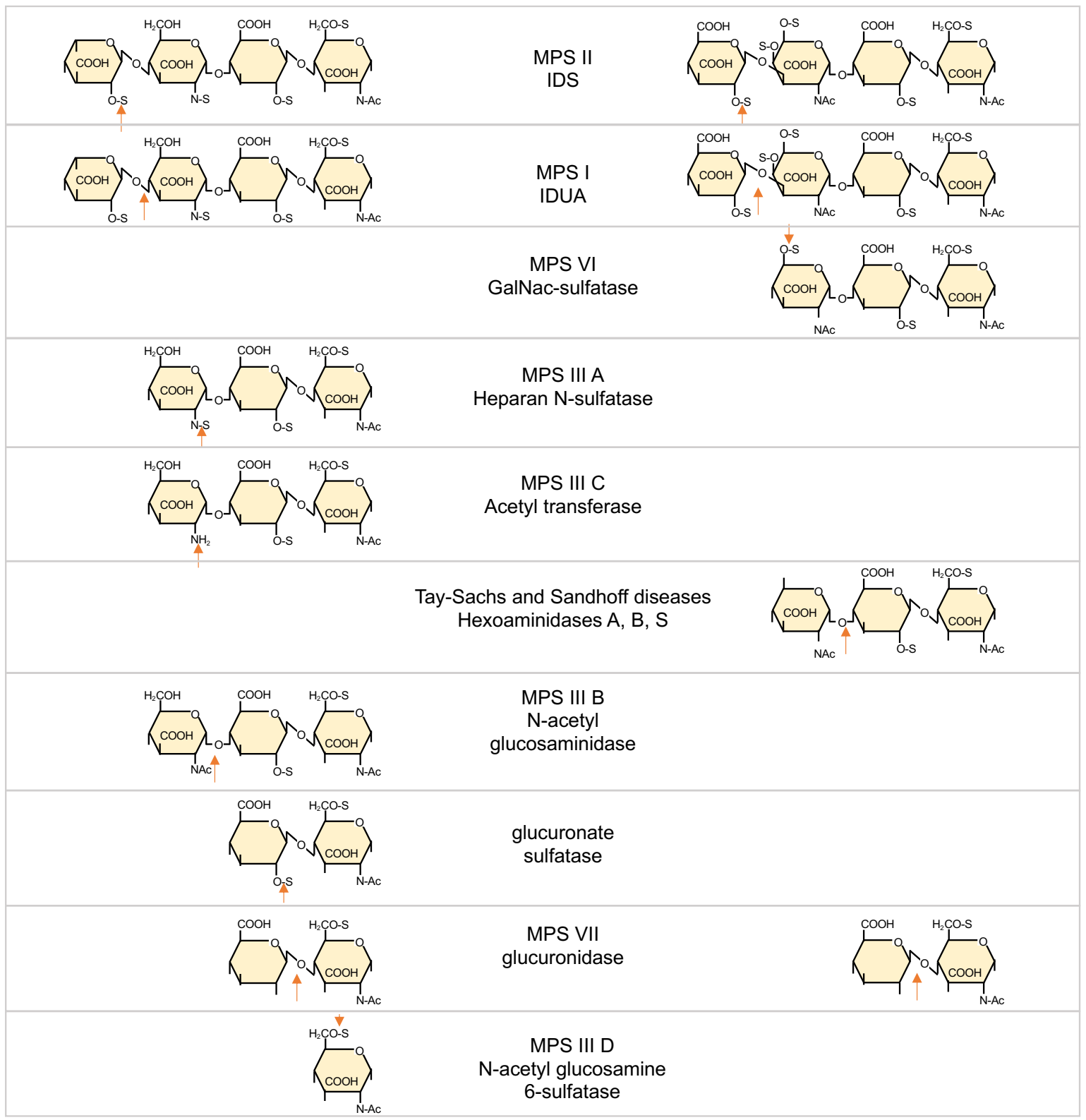

Figure 1. GAG catabolism begins with endohydrolysis of the polysaccharide chains to oligosaccharides. After this initial step, HS and DS oligosaccharides are degraded from their nonreducing ends (NRE) to monosaccharides and inorganic sulfate. The enzymes involved in the first two steps are IDS, which hydrolyzes the C2-sulfate ester bond of nonreducing terminal alpha-L-Iduronic acid (IdoA) residues in HS and DS and IDUA, which removes non-sulfated terminal alpha-L-IdoA residues. Under normal conditions, HS degradation produces IdoA and glucuronic acids (GlcA), while DS degradation results in IdoA and N-acetyl galactosamines (GalNAc). Defects in IDS activity result in accumulation of oligosaccharides with sulfated IdoA units on their NRE, while defects in IDUA activity result in oligosaccharides with non-sulfated IdoA units at their NRE [69]. 
Differences in sulfation degrees and patterns were reported in 1975 by Ramage and Cunningham [70]. Later analyses of fibroblasts isolated from patients with MPS I and unaffected human donors for HS degradation products revealed the presence of nonsulfated IdoA in patients with MPS I only. These NRE species were also found specifically in the urine of patients with MPS I. Likewise, the analysis of fibroblasts isolated from patients with MPS II revealed sulfated IdoA [71]. HS disaccharides with increased levels of sulfation are found in both MPS I and MPS II mice [42,72,73].

Patients with MPS suffering from joint contractures, skeletal deformities, and cardiac valvular thickening, but without CNS involvement showed lower levels of sulfated HS, supporting a connection between CNS manifestations and HS sulfation degree and pattern [68]. This led to the hypothesis that the presence of partially degraded HS with sulfate moieties at their NRE (as expected in MPS II) may be associated with CNS manifestations, while the lack of chemical moieties at the NRE (as in MPS I) is not [74].

Mechanistically, it is well understood that degree of sulfation and sulfation patterns determine the binding of HS to growth factors and other proteins [75-79], e.g., sulfation of HS is necessary for the binding of many HS-binding cofactors, such as CXCL12 [80] and FGF $[81,82]$.

\section{Disease-Specific Gene Expression}

Besides differences in HS and DS biochemistry, other factors may be involved in disease-specific manifestations. Recent in-depth transcriptome analysis in different MPS types identified disease-specific gene expression patterns for MPS I and MPS II [83-85]. Many of these genes were related to behavior, cell activation, and apoptosis. While a comprehensive analysis will be necessary to correlate specific manifestations to gene expression profiles, this is a promising approach to understand the different clinical outcomes between these different MPS types. It also remains to be established whether and how these differences in gene expression are related to the faulty GAG metabolism.

\section{Disease-Specific Proteomics}

A similar approach to disease-specific gene expression was taken when analyzing protein expression pattern in MPS I and MPS II. Proteomic analysis of urine samples may identify novel biomarkers for the diagnosis and prognosis, especially when the identified protein is associated with distinct MPS phenotypes. Two publications report a number of urinary proteins found in patients with MPS $[86,87]$. Some urinary proteins with upregulated expression were shared by patients with MPS I, II, and IV, while others were disease-specific [86]. Notably, patients with severe forms of MPS I or MPS II showed higher expression levels for specific proteins than their respective milder disease phenotypes. However, no overlap in the proteins identified in these two studies was observed. While the identification of disease-specific proteins in urine may lead to biomarkers that can be collected in a noninvasive manner, urinary proteins only present a section of the whole proteome. Proteomic analysis of whole MPS I mouse brain identified 50 proteins with a fold change $\geq 3.5$ compared to control mice [88]. Proteomic analysis of the hippocampus of MPS I mice found 32 proteins with differential expression [89]. However, little or no overlap was observed when comparing the protein expression patterns of these two studies. Cardona et al. [90] choose a functional approach when investigating the interactive proteome of IDS in mouse brain. Using a combination of affinity purification and mass spectrometry, they were able to identify 187 IDS-binding proteins in brain tissue extracts from C57BL/6 mice.

A thorough analysis of these different proteomic studies, possibly together with the above discussed transcriptome analyses, may allow the identification of disease-specific pathways and open new treatment options. 


\section{Disease Manifestation}

\subsection{Systemic Manifestations: Skin, Kyphosis, Corneal Clouding, Valvular Heart Disease}

A distinguishing feature in both severe and attenuated forms of MPS II are the presence of hypopigmented papules and nodules $[10,15,29,91,92]$. These skin manifestations are often present on the back, chest, neck, arms, and thighs and appear early in the disease [92-94]. The lesions are $2-10 \mathrm{~mm}$ in diameter, and can combine to form ridges or reticular patterns [29,92]. It is believed that these papules result from the coalescence of cytoplasmic vacuoles that subsequently release their mucinous contents into the extracellular space to form papules and nodules, as indicated by an abundance of extracellular deposition of metachromasia [93]. Histologically, the papules show irregularly organized collagen bundles separated by interfibrillar material [92]. While this skin manifestation is unique for MPS II, it is not exhibited in all patients with MPS II [92]. A possible link to HS accumulation is suggested by the observation of similar dermal nodules in scleromyxedema, where HS is hypothesized to promote binding of FGF1 to FGFR-1, and thereby promote fibroblast proliferation [95]. Another epidermal manifestation found mainly in patients with MPS II is Mongolian spots, which have been described in Asian patients with MPS II [30]. While the presence of Mongolian spots is common in Hispanic, Asian, and African newborns [96], they usually disappear during early childhood. In patients with MPS II this skin pigmentation persists well into late childhood [30].

One of the most recognizable distinctions between MPS II and MPS I is the presence of corneal clouding in the vast majority of patients with MPS I, while this manifestation is mild or absent in MPS II. The stromal layer of the cornea is made up of collagens, keratocytes, and proteoglycans carrying keratin (KS) and DS side chains, while HS plays only a minor role. Keratocytes synthesize and degrade both collagens and GAGs. The highly organized arrangement of uniform collagen fibrils and fibers is critical for the transparency of the cornea and is regulated by the DS-containing proteoglycans, decorin and biglycan [97] (Figure 2). Decorin consists of a collagen-binding core protein linked to one DS side chain. Mutations in the decorin gene are associated with the development of cloudy corneas, developing shortly after birth in patients with congenital stromal dystrophy $[98,99]$. The respective contributions of the decorin core protein and the attached DS side chains were resolved in an elegant experiment using decorin-deficient fibroblasts transfected with GAG-free decorin. Collagen fiber diameters showed significant increases, indicating that the DS side chain of decorin controls collagen fiber diameters [100].

In MPS I, DS accumulates within the keratocytes, causing them to swell and lose their characteristic morphology [101]. Partially degraded DS also accumulates in granules throughout all corneal layers [102]. Both GAG deposits cause the disruption of the parallel arrangement of the collagen fibril, leading to corneal clouding $[103,104]$. The relatively lower levels of DS in MPS II may contribute to delayed development of corneal clouding, or lack thereof.

Kyphosis in MPS is characterized by poor bone growth in the anterior-superior aspect of the cranial lumbar vertebrae, resulting in anterior wedging and posterior displacement of the vertebral body [26,105]. It is unclear why kyphosis is more frequently observed in patients with MPS I. However, patients with Ehlers-Danlos syndrome (musculocontractural type 1), a disease caused by lack of dermatan sulfotransferase and subsequent abnormal DS sulfation levels [106], also characteristically develop thoracolumbar kyphosis [107]. This suggests an involvement of abnormal DS sulfation in kyphosis in patients with MPS I as well.

Cardiac valve disease is common in patients with MPS I, II, and VI [108]. The relative absence of cardiac valve involvement in MPS III (accumulation of HS only) suggests a correlation between cardiac valve dysfunction and accumulation of DS, rather than HS [109]. This perception is supported by findings of cardiac valve thickening in the majority of patients with MPS I or MPS VI $[13,35,36,110,111]$ and only $~ 50 \%$ of patients with MPS II [10]. Mechanistically, the relative prominence of DS compared to other GAGs in cardiac valves may contribute to the underlying cause [112]. 


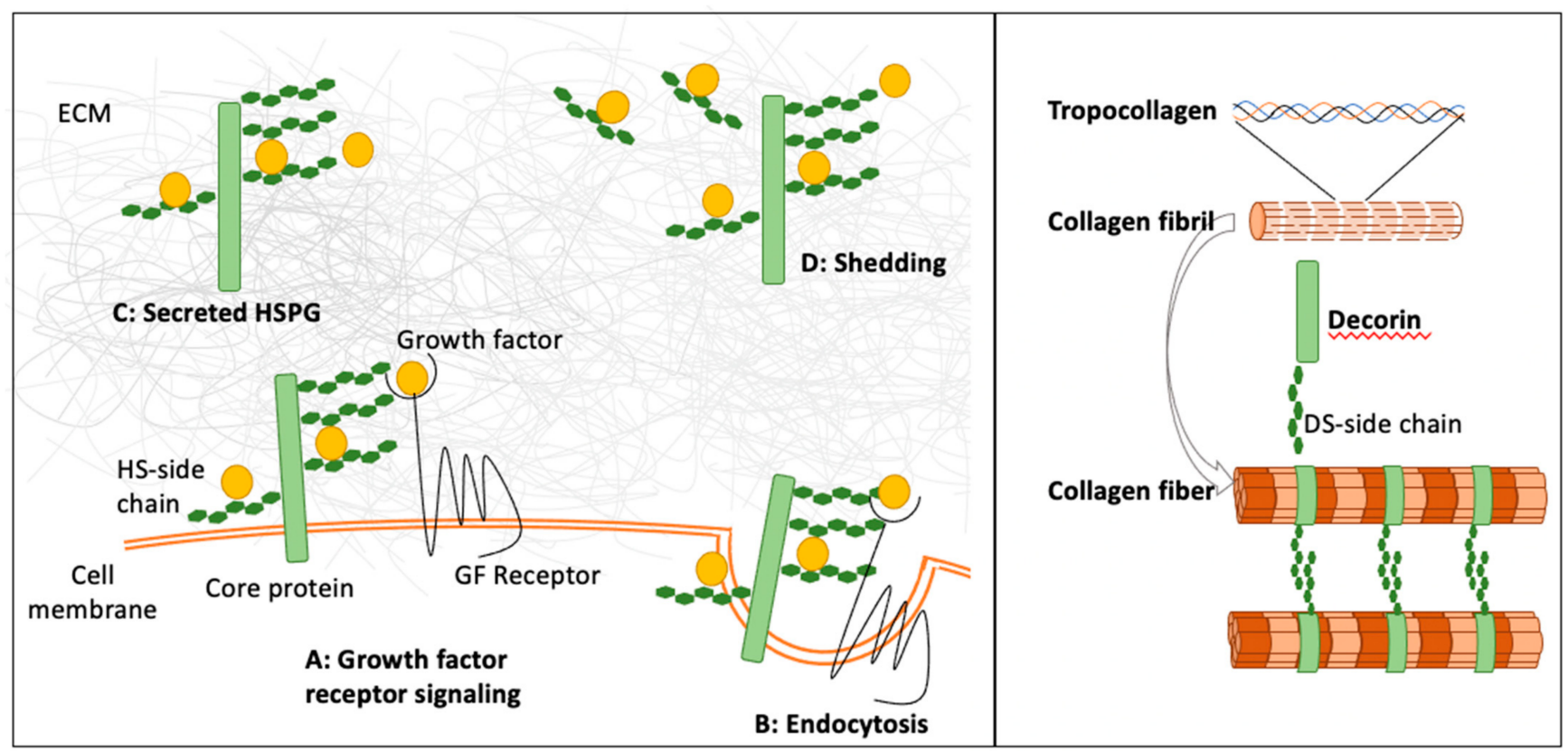

Figure 2. Examples of the biological functions of DS- and HS-containing proteoglycans. (Left panel) HSPGs affect growth factors and morphogens in a number of ways that are dependent on their sulfation pattern, their cellular localization, and the core protein [76]. HSPGs can be tethered to the cell surface (syndecan and glypicans), where they retain growth factors and activate receptor signaling (A), or mediate clearance of growth factors by endocytosis of growth factors and their receptors (B). HSPGs promote and stabilize the ternary complex between the growth factor, HS, and growth factor receptor. The formation of the ternary complex is enhanced by higher sulfation levels. Other HSPGs (perlecan and agrin) are secreted and localized in the ECM, where they can trap growth factors, and thus generate growth factor reservoirs and prevent their diffusion (C). HSPGs and HS can also be released by shedding, and thus become soluble (D). Soluble HSPGs can facilitate growth factor dispersal or movement through the extracellular space. (Right panel) During collagen fibrillogenesis, procollagen is synthesized as a triple helix that self-assembles into striated collagen fibrils after cleavage of the $\mathrm{C}$ - and N-terminal propeptides. The collagen fibrils are then arranged into uniform collagen fibers. The precise spacings between collagen fibers are maintained by the DS-containing proteoglycan decorin.

\subsection{Neurological Involvement: White Matter Abnormalities, Neurocognitive Functioning, Behavioral Manifestations, Seizures, Sleep Abnormalities}

GAG levels in the brain are significantly increased for MPS I and MPS II (up to sixfold) [113,114]. GAG deposits may impair CSF reabsorption, leading to enlarged perivascular spaces (PVS), communicating hydrocephalus and ventriculomegaly [61,115]. Indeed, central nervous system (CNS) morbidities in MPS are well known, including major structural effects, such as hydrocephalus and cervical spinal cord compression $[9,116,117]$, as well as atrophy in some severe, progressive phenotypes [118]. Some more recent sophisticated volumetric imaging studies have also revealed other important structural findings that are less obvious in a clinical scan for a single patient, such as abnormalities in white matter volume development, particularly when compared to unaffected controls [119-121]. White matter involvement has been quantified in both MPS I and MPS II across the spectrum of disease. In the cognitively severe type of MPS I, white matter dysfunction is a common finding post-HSCT [122]. However, even in patients with the more attenuated type of MPS I disease without a history of HSCT, white matter abnormalities are prevalent [120]. These white matter abnormalities are also present in both the cognitively severe and attenuated forms of MPS II, indicating brain-based effects of MPS even in the "non-neuronopathic" patients.

In addition to structural abnormalities, patients with MPS also show evidence of functional CNS effects of disease, including neurocognitive deficits. In severe, "neuronopathic" MPS types, developmental delay, neurocognitive regression, behavioral changes, 
and sleep disturbances have been described $[9,117,123]$. In patients with severe MPS I, cognitive decline and/or delay in speech and language milestones is common [39]. Cognitive functioning in patients at the severe end of the MPS I disease spectrum typically reaches a plateau before 2 years of age, and is followed by rapid deterioration with aging to a profoundly impaired state by age $4[22,124]$. In contrast, in patients with severe MPS II, cognitive development reaches a plateau at around a mean age of 4-4.5 years of age, though with significant variability. Unlike the rapid intellectual loss that is evident in severe MPS I patients, the velocity of intellectual regression in the cognitively severe type of MPS II is much more complicated to calculate, due to a protracted plateau of developmental stagnation that can last years [4].

In the attenuated forms of MPS I and MPS II, somatic disease is common and is associated with poorer functioning. While many individuals with the attenuated form of MPS I have average intellect, below average cognitive functioning has been reported in a proportion, with genotype and somatic disease burden predicting neurocognitive ability $[39,125,126]$.

Deficits in attention span, and related to white matter abnormalities, have also been reported in MPS I patients with the attenuated form of disease [120]. In patients with the less progressive, attenuated MPS II phenotype, intelligence is typically normal and remains stable; however, deficits in attention, with evidence of difficulties with executive functioning and visual-motor skills, have been noted [121]. Similar to findings in the MPS I population, there is also evidence of associations between somatic disease burden and neurocognitive functioning, namely in the areas of attention [121].

The behavioral phenotype of young patients with the cognitively severe type of MPS I has generally been described as social, compliant, and somewhat fearful $[9,127,128]$. These characteristics have also been corroborated in work comparing the behavioral phenotypes of young patients with MPS III to MPS I, with MPS I patients being more likely to stay close to caregivers, more likely to startle in response to loud noises, and being more compliant with caregiver commands [129]. While behavioral manifestations are not commonly seen early on, as MPS I patients age, there are emerging difficulties with attention [122,130]. Later in adolescence, there is also evidence that MPS I patients experience low self-esteem, depression, and social withdrawal. Recent work has also reported a high proportion of lateonset psychiatric manifestations, including depression, psychotic episodes (independent of depression), hyperactivity, inattention, and dementia that emerge approximately 15 years post-HSCT [131-133].

In contrast, patients at the cognitively severe, "neuronopathic" end of the MPS II disease spectrum demonstrate neurobehavioral symptoms that are significant and represent a characteristic feature of this phenotype [134]. Previously described as "aggressive" in early literature, accumulating research has been able to parse out these neurobehavioral symptoms to include difficulties with focus/attention, hyperactivity, impulsivity, behavior manifestations (e.g., destructiveness, aggressiveness, defiance), sensation-seeking behavior, poor emotional regulation (temper tantrums, excitable, anxious), sleep disturbance, and perseverative chewing behavior $[7-9,12,128,135]$. As such, it has been posited that the aggressive behavior often observed in children with severe MPS II may be caused by a combination of frustration, limited communication skills, anxiety, sensory-seeking behavior, and poor emotional regulation [136,137]. These symptoms generally worsen in intensity and frequency with age, until they subside with worsening overall disease progression.

Seizures are rare in patients with MPS I and, if present, are typically resolved after HSCT [38], but are frequent in MPS II patients with CNS involvement $[138,139]$. In contrast, seizures are not commonly reported in the patients with MPS II lacking CNS manifestations [140].

Sleep disturbances in children with MPS I appear to be related to upper respiratory manifestations, rather than behavioral issues [128], whereas, in children with MPS II, sleep disturbances are multifactorial, with one factor being CNS involvement, as they are more frequent in neuronopathic patients [128]. Many MPS II patients experienced reduced rapid 
eye movement sleep, night-time wakening, difficulty settling, or insomnia, which has been described as likely attributed to sleep apnea or seizure-like activity. Notably, behavioral and sleep manifestations represent early clinical markers of CNS involvement in patients with neuronopathic MPS II.

\section{HS in Neurological Manifestations}

HS is produced in astrocytes, neurons, and oligodendrocytes [141] and is involved in many aspects of neuronal development [142]. Based on the central role of HS in binding to growth factors and chemokines, abnormal HS sulfation may interfere with proper neuronal proliferation and survival [143-145]. Aberrant presentation of HS has also been implicated in the activation of neuroinflammation, which is often observed in mouse models for both MPS I and MPS II [61,72]. Mechanistically, immune responses can be activated by soluble HS acting as TLR4 agonists $[146,147]$. This activation appears to be further enhanced by high levels of sulfation [148].

Another potential mechanism links the neurological pathology in MPS to Alzheimer's Disease, Huntington's Disease, and Parkinson's Disease [149]. HS associates with tau and alpha-synuclein and can promote their aggregation, cellular uptake, and transcellular propagation of fibrils [150-152]. Since sulfation of HS is necessary for tau binding [151], over-sulfated HS in MPS II may promote tau and alpha-synuclein binding, while the presence of non-sulfated HS in MPS I may be protective. This hypothesis remains to be tested.

Finally, lysosomal storage of GAG may also affect the activity of other lysosomal hydrolases, causing an increase in storage of glycosphingolipids $[153,154]$ and gangliosides GM2 and GM3 [113,114,155]. However, cellular distributions of GAGs and gangliosides GM2 and GM3 show only limited overlap in mouse brains, so that other mechanisms may be involved in the accumulation of GM2 and GM3 [156].

\section{Animal Models}

While several animal models, including dogs, cats, and mice, exist for MPS I [157], no animal affected by MPS II was described until 1998. In 1998, a male Labrador retriever was successfully diagnosed with MPS II [158]. In this spontaneous model, the animal showed characteristic coarse facial features, with an enlarged tongue, ataxia, corneal clouding in one eye, and progressive neurologic decline. MPS II was confirmed by DNA analysis and the mother was identified as a carrier of a defective IDS gene. The exact nature of the genetic defect was not described. While several of the manifestations resembled those in children with MPS II, skeletal abnormalities were not observed. The first knock-out mouse for MPS II was generated by Muenzer et al. [159]. Since then, a number of additional knock-out mice were generated [73,160-169]. The animals are born without evident disease manifestations. While there are few differences in the age of disease onset, all MPS II mouse models show increased excretion of GAG, with GAG accumulation in the peripheral organs and the brain (Table 3). Foamy cells are observed in most tissues. The animals have coarse fur and alopecia, deformations in their joints and skeleton, with apparent thickening of the zygomatic bones, thickened digits leading to claw-like appearances of the front paws, coarse facial features, and a decline in activity.

Animal models aide in the understanding of the pathology of the disease and preclinical studies. However, species-specific disease manifestations need to be considered. Canine animal models for MPS I tend to show milder manifestations compared to humans afflicted by the disease [170-172]. The introduction of exact mutations in mouse models provides insights into the genetics of the disease $[173,174]$. However, the small size and short lifespan of mice need to be considered when evaluating therapeutic efficiency.

\section{Natural History}

Systemic and neurologic manifestations tend to appear earlier in patients with severe MPS I than in patients with severe MPS II [175], resulting in relatively late diagnosis of 
MPS II (Table 2). A similar trend is also observed in the mouse models for MPS I and MPS II (Table 3).

Table 2. Earliest time for manifestations in patients with MPS IH and MPS IIA.

\begin{tabular}{ccc}
\hline & MPS IH & MPS IIA \\
\hline Cognitive development & $\begin{array}{c}\text { Progressive cognitive decline beginning at } \\
\text { age 6-15 months [18,39,176-178] }\end{array}$ & $\begin{array}{c}\text { Normal until age 3-4 years, followed by } \\
\text { plateau and rapid decline [4,179] }\end{array}$ \\
\hline Coarse facial features & $6-12$ months [18] & 2-4 years [23] \\
\hline Hearing loss & $6-12$ months [20] years [32] & 6 years [23] \\
\hline Cardiac valve disease & 1 year [18] & 6 years [23,24] \\
\hline Kyphosis & 1 year [18] & Normal to accelerated until age 5-6 years \\
[23,180]
\end{tabular}

\section{Treatment}

For a comprehensive discussion of current and exploratory treatments for MPS I we refer to earlier reviews $[188,189]$.

The FDA approved treatment of MPS II with recombinant IDS in 2006. Currently, there are two recombinant IDS enzymes available for enzyme replacement therapy (ERT): idursulfase (Elaprase ${ }^{\circledR}$ ) or idursulfase beta (Hunterase ${ }^{\circledR}$ ) [190]. IDS is administered weekly at $0.5 \mathrm{mg} / \mathrm{kg}$ as an intravenous infusion. ERT has significantly lowered the risk of death in patients with MPS II [31,191-193] and has had a beneficial effect on many of the biochemical and systemic manifestations, including reduced urinary GAG excretion levels, decreased volumes of liver and spleen, and increased cardiopulmonary function and average walking distance (Table 4) [194,195]. However, it is believed that the enzyme does not cross the blood-brain barrier (BBB) and is, therefore, not likely to have an effect on CNS disease among severely affected patients [196-198].

Table 4. Outcome of HSCT and ERT on manifestations in patients with MPS II.

\begin{tabular}{|c|c|c|}
\hline Manifestation & ERT & HSCT \\
\hline Hepatosplenomegaly & Improved [192,199-205] & $\begin{array}{c}\text { Improved [206,207] } \\
\text { Improved (case studies } n<10)[208-210]\end{array}$ \\
\hline Skeletal manifestations & No change [204] & $\begin{array}{l}\text { No change (case study } n=1 \text { ) [208] } \\
\text { Improved (case study } n=1 \text { ) [198] }\end{array}$ \\
\hline Poor growth & Minimal effect $[199,211]$ & $\begin{array}{c}\text { Improved [212] } \\
\text { Improved (case study } n=1 \text { ) [198] }\end{array}$ \\
\hline Coarse facial features & Improved [201] & $\begin{array}{c}\text { Improved [206] } \\
\text { Improved (case studies } n<10)[208,210,213,214]\end{array}$ \\
\hline Upper respiratory function & Improved [205] & Improved [206,207] \\
\hline
\end{tabular}


Table 4. Cont.

\begin{tabular}{|c|c|c|}
\hline Manifestation & ERT & HSCT \\
\hline Lower respiratory function & Improved [191,199,201,203] & NA \\
\hline Heart hypertrophy & Improved [191,194,199] & Improved [215] \\
\hline Valvular heart disease & $\begin{array}{c}\text { Prevention (when administered very } \\
\text { early) [199] } \\
\text { No change [204] }\end{array}$ & $\begin{array}{c}\text { Stabilization/improved }[206,215] \\
\text { Improved (case studies } n<10)[209,216,217]\end{array}$ \\
\hline Joint stiffness & $\begin{array}{c}\text { No change }[199,200] \\
\text { Improved (shoulders) }[195,205]\end{array}$ & $\begin{array}{c}\text { No change [206] } \\
\text { No change (case studies } n<10)[214,216,218,219] \\
\text { Improved }[207,220] \\
\text { Improved (case studies } n<10)[208,209,213]\end{array}$ \\
\hline Endurance & Improved [192,194,195,201] & Improved [217] \\
\hline Skin, thickened with pebble & Improved [199,221,222] & Improved (case studies $n<10)[214,216,218,223]$ \\
\hline Cognitive impairment & No change $[195,201]$ & $\begin{array}{c}\text { Improved [217] } \\
\text { Improved (case studies <10) }[198,217] \\
\text { Worsening (case studies } n<10) \\
{[208-210,219,224]}\end{array}$ \\
\hline Apnea & $\begin{array}{l}\text { Improved/stabilized apnea } \\
\text { (obstructive) [182] }\end{array}$ & $\begin{array}{c}\text { Improved apnea (not clarified whether obstructive } \\
\text { or central) [207] }\end{array}$ \\
\hline Diarrhea & Improved/stabilized [205] & NA \\
\hline Activity of daily living (ADL) & NA & Improved [207,215,225] \\
\hline
\end{tabular}

Treatment of MPS I consists of ERT in attenuated cases and hematopoietic stem cell transplantation (HSCT) in patients with severe MPS I, where early transplantation can stem many of the CNS manifestations of the disease [188]. Indeed, MPS I was the first metabolic disease to have a successful disease-modifying therapy, e.g., HSCT [226,227].

Early reports of the outcome of HSCT in patients with severe MPS II were not as promising [224,228], specifically regarding neurologic decline [178,208,209,224]. Together with these earlier reports and the risks associated with HSCT, transplants have been less common as treatment for MPS II in most Western countries. The demonstration of donor cells in the CNS of patients with MPS II that underwent HSCT caused a renewed interest in HSCT for the treatment of CNS manifestations [229]. More recent studies showed indications of improved activities of daily living and systemic manifestations (Table 4). The differences in outcomes between the original and the later studies may have been caused by suboptimal transplantation material $[209,224]$ or more established neurological deficit at treatment in the earlier transplantations [208,209,224]. Unlike MPS I, manifestations in MPS II emerge later in life and many of the earlier transplants were administered after 2 years of age, when a beneficial effect on the CNS is less likely $[178,230]$. Based on the new studies and HSCT-related lowered mortality [206], HSCT is currently an accepted treatment for patients with MPS II in Japan, China, and Brazil [198,212,215,220,231]. A retrospective study of four children diagnosed with MPS II, who received HSCT, indicated overall favorable outcomes, with improved or stabilized somatic and neurocognitive manifestations [217].

\subsection{Treatment in Animals}

In a dose-finding study, the effects of systemic IDS administration at $0.1-1 \mathrm{mg} / \mathrm{kg} /$ week were investigated in MPS II mice. A dose of $0.5 \mathrm{mg} / \mathrm{kg} /$ week successfully reduced GAG levels in liver, heart, and spleen, but not in kidney or lung [232]. Treatment with $1 \mathrm{mg} / \mathrm{kg}$ /week further reduced GAG levels in kidney and lung. No significant reduction in brain GAG was achieved at any dose [232]. Tissue specific differences in IDS levels were observed with the majority of enzyme accumulating in the liver, while other tissues, such as kidneys, heart, lungs, and brain accumulated $<1 \%$ of the administered dose. [232]. Other 
studies reported significantly reduced HS and DS levels in all tissues, except for brain at $0.5 \mathrm{mg} / \mathrm{kg} /$ week. However, both HS and DS levels remained above those of control mice [48].

For ERT, the lack of benefit on the CNS has been largely attributed to the inability of IDS to cross the BBB. However, this point of view has been challenged by studies demonstrating that high systemic levels of enzyme can penetrate the CNS and ameliorate neurologic manifestation in MPS II animals $[166,168,233]$. While the IDS enzymatic activity reached only $2 \%$ of that observed in wildtype brain, GAG accumulations in brain tissues were significantly reduced $[166,168,234]$. Thus, the standard dose of $0.5 \mathrm{mg} / \mathrm{kg} /$ week may be too low to affect the CNS. Indeed, systemic administration of $1.2 \mathrm{mg} / \mathrm{kg} /$ week of human IDS was demonstrated to prevent progression of CNS defects in MPS II mice. Improvement was even observed in old animals (7 months) that received a high dose (10 mg/kg/week) of IDS [168]. These results were confirmed when systemic administration of $2.0 \mathrm{mg} / \mathrm{kg} /$ week recombinant human IDS resulted in significant reduction of GAG brain levels, attenuated enlarged ventricles, normalization of Purkinje cell morphology in the cerebellum, and reduction in apoptosis [235].

Delivery of IDS via adeno-associated virus (AAV) gene transfer in mice resulted in high levels of circulating IDS, with beneficial effects on systemic and CNS manifestations $[162,168,234]$. Another method to achieve high levels of IDS is through ex vivo genetic modification of HSC. Transplantation of lentiviral transduced HSC resulted in an increase in serum IDS levels several-fold higher than wild type [167,236]. GAG accumulation in all tested tissues, including the brain, was resolved. and deterioration of neurofunction was prevented [167]. Moreover, bone manifestations were affected with significant reduction of zygomatic arch width. In-depth analysis of bone parameters revealed higher osteoclast number, suggesting activation of bone resorption [236].

\subsection{Experimental Therapies and Clinical Trials}

The high prevalence of CNS manifestations in patients with MPS II and ineffectiveness of ERT has motivated the development of experimental therapies with the aim of IDS delivery to the brain. Early diagnosis is an essential factor to prevent CNS manifestations, as they cannot be reversed. Newborn screening has been suggested to be implemented to aide in the early diagnosis of MPS. More than 600 mutations have been identified for the IDS gene locus. Several studies investigated correlations between genotypes to phenotypes, but, to date, no clear correlation has been established [237,238]. Deletions, recombinations, frameshift, and nonsense mutations are often associated with a severe form of the disease, while most missense mutations are found in patients with attenuated disease [239-243].

\subsubsection{ERT to the Brain}

Direct administration of IDS in MPS II mice via ICV or lumbar IT infusion resulted in successful delivery and morphological improvements in the brain [244]. ICV injections lowered HS levels in the CSF and in brain tissue, and yielded improved cognitive function evaluated by open-field and fear-conditioning tests [245]. This method was further advanced by enabling continuous IT infusion through an osmotic pump, which decreased GAG accumulation and vacuolization [246]. Clinical trials revealed significant reduction of GAGs in the CSF after enzyme administration via an intrathecal drug delivery device [247] (NCT00920647 and NCT00937794). An extension study (NCT01506141) to trial NCT00920647 revealed mixed results with some patients showing stable scores, while cognition worsened in others [248]. However, no beneficial effect on neurocognitive function could be established in a phase II/III study enrolling children with severe MPS II and a mild to moderate level of cognitive impairment (NCT02055118). A second phase II/III extension clinical trial (NCT02412787) [249] is currently active, but not recruiting. Recent results of a 100-week ongoing phase I/II clinical trial conducted in Japan (JMACCT CTR JMA-IIA00350) in six children with severe MPS II showed a decrease of CSF HS levels ( $>50 \%$ decrease) and promising effects on cognitive development [250]. 


\subsubsection{Shuttling of IDS Across the BBB}

Tissue-specific delivery of peripherally administered IDS has been attempted by targeting receptors present on the luminal side of the BBB.

Systemic administration of IDS fused to an anti-human transferrin receptor antibody (JR141) in 10-week-old MPS II mice resulted in significant reduction of HS accumulation in the CNS and prevented neurodegeneration [251-253]. A phase I/II clinical trial (NCT03128593) in 14 patients with MPS II resulted in significant reduction of HS levels in the CSF at a dose of $2 \mathrm{mg} / \mathrm{kg} /$ week [254]. The subsequent phase II/III clinical trial (NCT03568175) not only confirmed HS level reduction, but also demonstrated improved neurocognition in $21 / 28$ patients [255]. A Brazilian phase I/II dose-escalation clinical trial (NCT03359213) confirmed the $2 \mathrm{mg} / \mathrm{kg}$ / week dose as most effective with minimal side effects [256]. Patients showed stabilization of neurocognition and adaptive behavior, and indications for improved neurodevelopment even in older patients. An extension study for this trial (NCT03708965) is currently active, but not recruiting.

Fusing IDS to a monoclonal antibody against the human insulin receptor allowed the transport of enzyme across the BBB in rhesus monkeys [257,258]. A phase I/II clinical trial (NCT02262338) to evaluate safety of this product was completed, with no results posted yet.

\subsubsection{Gene Therapy: In Vivo}

ICV delivery of AAV9 vector transducing the IDS coding sequence resulted in highlevel IDS, both in circulation and the brain, accompanied by prevention of development of cognitive deficits observed in untreated controls $[160,169,233]$. Importantly AAV9 has the ability to cross the BBB [259] and has been successfully used to deliver lysosomal enzyme to the CNS in mouse models of MPS III [260,261]. Two clinical trials (NCT03566043, NCT04571970) are currently recruiting patients with MPS II for targeted delivery of the IDS gene to the CNS using AAV9.

\subsubsection{Genome Editing}

The zinc-finger nuclease (ZFN)-mediated gene editing technology was used to insert the IDS coding sequence into the albumin locus for high-level protein expression [262]. Delivery of the construct by AAV8 vector to hepatocytes in MPS II mice resulted in significant increases in IDS activity and GAG reduction in blood and peripheral tissues and GAG reduction in the brain, which was associated with prevention of cognitive impairment [233]. A phase I/II clinical trial (NCT03041324) introducing the IDS coding sequence via ZFN-mediated genome editing resulted in reduction of GAG in the urine, although no IDS enzyme activity was detected in the plasma [263].

\subsubsection{Oligodendrocyte-like Cells, DUOC-01, to Accelerate CNS Engraftment of Donor Cells}

The remarkable ability of HSCT to prevent CNS manifestations in MPS is most likely due to the engraftment of donor-derived microglia or microglia-like cells in the CNS [264]. However, successful engraftment requires repopulation of the recipient myeloid compartment through donor hematopoietic progenitors [265,266], a process that takes over 6 months in transplanted mice [267]. During this time the decline in neurocognitive function continues. Thus, HSCT must be initiated well before the onset of neurologic decline. Kurtzberg et al. at Duke University developed a novel cell product, the Duke O Cell, or DUOC-01. These cells are derived from umbilical cord blood (UMCB) and efficiently treat demyelinating conditions [268]. DUOC-01 are derived from UMBC CD14+ monocytes and resemble oligodendrocyte-like cells [269]. DUOC-01 are delivered intrathecally after systemic transplantation to accelerate delivery of donor cells to the CNS, thereby bridging the gap between systemic transplant and engraftment of cells in the CNS and preventing disease progression. A phase I clinical trial (NCT02254863) is currently recruiting partici- 
pants to evaluate the effect of intrathecal delivered DUOC-01 after UMCB transplantation in patients with MPS II and other inborn errors of metabolism.

\section{Conclusions}

Disease-specific manifestations of the closely related diseases MPS I and MPS II may be caused by differences in levels of accumulated storage materials and their sulfation patterns. The diseases' major storage molecules, dermatan sulfate (DS) and heparan sulfate (HS), have unique functions, which can be further modified by sulfation levels. It remains unclear whether the apparent resistance of MPS II neurocognitive impairment to HSCT is caused by these biochemical differences, or whether early reports were artifacts of experimental design. It will be necessary to resolve this issue to determine whether patients with MPS II can be successfully treated with HSCT, or whether future therapies can be developed to ensure sufficient delivery of the therapeutic enzyme to the CNS.

Author Contributions: All authors have contributed to the writing, review, and editing. All authors have read and agreed to the published version of the manuscript.

Funding: This research received no external funding.

Institutional Review Board Statement: Not applicable.

Informed Consent Statement: Not applicable.

Acknowledgments: We gratefully acknowledge Julie Eisengart for her expertise, assistance and critical revision of the manuscript.

Conflicts of Interest: C.S.H., J.W. and R.S.M. are employees of Immusoft Corporation. T.C.L. is a paid consultant of Immusoft Corporation.

\section{References}

1. Hunter, C. A Rare Disease in Two Brothers. Proc. R. Soc. Med. 1917, 10, 104-116. [CrossRef] [PubMed]

2. Hashimoto, A.; Kumagai, T.; Mineta, H. Hunter Syndrome Diagnosed by Otorhinolaryngologist. Case Rep. Otolaryngol. 2018, 2018, 1-4. [CrossRef] [PubMed]

3. Khan, S.A.; Peracha, H.; Ballhausen, D.; Wiesbauer, A.; Gautschi, M.; Mason, R.W.; Giugliani, R.; Suzuki, Y.; Orii, K.E.; Orii, T.; et al. Epidemiology of mucopolysaccharidoses. Mol. Genet. Metab. 2017, 121, 227-240. [CrossRef]

4. Shapiro, E.; Eisengart, J. The natural history of neurocognition in MPS disorders: A review. Mol. Genet. Metab. 2021, 133, 8-34. [CrossRef]

5. Broomfield, A.; Davison, J.; Roberts, J.; Stewart, C.; Hensman, P.; Beesley, C.; Tylee, K.; Rust, S.; Schwahn, B.; Jameson, E.; et al. Ten years of enzyme replacement therapy in paediatric onset mucopolysaccharidosis II in England. Mol. Genet. Metab. 2020, 129, 98-105. [CrossRef] [PubMed]

6. Mohamed, S.; He, Q.Q.; Singh, A.A.; Ferro, V. Mucopolysaccharidosis type II (Hunter syndrome): Clinical and biochemical aspects of the disease and approaches to its diagnosis and treatment. Adv. Carbohydr. Chem. Biochem. 2020, 77, 71-117. [CrossRef] [PubMed]

7. Al Sawaf, S.; Mayatepek, E.; Hoffmann, B. Neurological findings in Hunter disease: Pathology and possible therapeutic effects reviewed. J. Inherit. Metab. Dis. 2008, 31, 473-480. [CrossRef] [PubMed]

8. Holt, J.B.; Poe, M.D.; Escolar, M.L. Natural progression of neurological disease in mucopolysaccharidosis type II. Pediatrics 2011, 127, e1258-e1265. [CrossRef]

9. Neufeld, E.F.; Muenzer, I. The Metabolic E Molecular Basis of Inherited Disease, 8th ed.; Scriver, C.R., Beudet, A.L., Sly, W.S., Valle, D., Eds.; McGraw-Hill: New York, NY, USA, 2001; Volume III.

10. Wraith, J.E.; Scarpa, M.; Beck, M.; Bodamer, O.A.; De Meirleir, L.; Guffon, N.; Meldgaard Lund, A.; Malm, G.; Van der Ploeg, A.T.; Zeman, J. Mucopolysaccharidosis type II (Hunter syndrome): A clinical review and recommendations for treatment in the era of enzyme replacement therapy. Eur. J. Pediatr. 2008, 167, 267-277. [CrossRef]

11. Martin, R.; Beck, M.; Eng, C.; Giugliani, R.; Harmatz, P.; Muñoz, V.; Muenzer, J. Recognition and diagnosis of mucopolysaccharidosis II (Hunter syndrome). Pediatrics 2008, 121, 377-386. [CrossRef] [PubMed]

12. Young, I.D.; Harper, P.S. The Natural History of the Severe Form of Hunter's Syndrome: A Study Based on 52 Cases. Dev. Med. Child Neurol. 1983, 25, 481-489. [CrossRef]

13. Pastores, G.M.; Arn, P.; Beck, M.; Clarke, J.T.R.; Guffon, N.; Kaplan, P.; Muenzer, J.; Norato, D.Y.J.; Shapiro, E.; Thomas, J.; et al. The MPS I registry: Design, methodology, and early findings of a global disease registry for monitoring patients with Mucopolysaccharidosis Type I. Mol. Genet. Metab. 2007, 91, 37-47. [CrossRef] 
14. D'Aco, K.; Underhill, L.; Rangachari, L.; Arn, P.; Cox, G.F.; Giugliani, R.; Okuyama, T.; Wijburg, F.; Kaplan, P. Diagnosis and treatment trends in mucopolysaccharidosis I: Findings from the MPS I registry. Eur. J. Pediatr. 2012, 171, 911-919. [CrossRef] [PubMed]

15. Tylki-Szymańska, A. Mucopolysaccharidosis type II, Hunter's syndrome. Pediatr. Endocrinol. Rev. 2014, 12, 107-113. [PubMed]

16. Scarpa, M.; Almássy, Z.; Beck, M.; Bodamer, O.; Bruce, I.A.; De Meirleir, L.; Guffon, N.; Guillén-Navarro, E.; Hensman, P.; Jones, S.; et al. Mucopolysaccharidosis type II: European recommendations for the diagnosis and multidisciplinary management of a rare disease. Orphanet J. Rare Dis. 2011, 6, 72. [CrossRef] [PubMed]

17. Mendelsohn, N.J.; Harmatz, P.; Bodamer, O.; Burton, B.K.; Giugliani, R.; Jones, S.A.; Lampe, C.; Malm, G.; Steiner, R.D.; Parini, R. Importance of surgical history in diagnosing mucopolysaccharidosis type II (Hunter syndrome): Data from the Hunter Outcome Survey. Genet. Med. 2010, 12, 816-822. [CrossRef] [PubMed]

18. Beck, M.; Arn, P.; Giugliani, R.; Muenzer, J.; Okuyama, T.; Taylor, J.; Fallet, S. The natural history of MPS I: Global perspectives from the MPS I Registry. Genet. Med. 2014, 16, 759-765. [CrossRef] [PubMed]

19. Leroy, J.G. Clinical Definition of the Hurler-Hunter Phenotypes. Am. J. Dis. Child. 1966, 112, 518-530. [CrossRef]

20. Kiely, B.T.; Kohler, J.L.; Coletti, H.Y.; Poe, M.D.; Escolar, M.L. Early disease progression of Hurler syndrome. Orphanet J. Rare Dis. 2017, 12, 32. [CrossRef] [PubMed]

21. Fesslová, V.; Corti, P.; Sersale, G.; Rovelli, A.; Russo, P.; Mannarino, S.; Butera, G.; Parini, R. The natural course and the impact of therapies of cardiac involvement in the mucopolysaccharidoses. Cardiol. Young 2009, 19, 170-178. [CrossRef] [PubMed]

22. Muenzer, J.; Wraith, J.E.; Clarke, L.A. Mucopolysaccharidosis I: Management and treatment guidelines. Pediatrics 2009, 123, 19-29. [CrossRef]

23. Wraith, J.E.; Beck, M.; Giugliani, R.; Clarke, J.; Martin, R.; Muenzer, J. Initial report from the Hunter Outcome Survey. Genet. Med. 2008, 10, 508-516. [CrossRef] [PubMed]

24. Link, B.; Lapagesse de Camargo Pinto, L.; Giugliani, R.; Wraith, J.E.; Guffon, N.; Eich, E.; Beck, M. Orthopedic manifestations in patients with muco polysaccharidosis type II (Hunter syndrome) enrolled in the Hunter Outcome Survey. Orthop. Rev. (Pavia) 2010, 2, 16. [CrossRef] [PubMed]

25. Aldenhoven, M.; Wynn, R.F.; Orchard, P.J.; O’Meara, A.; Veys, P.; Fischer, A.; Valayannopoulos, V.; Neven, B.; Rovelli, A.; Prasad, V.K.; et al. Long-term outcome of Hurler syndrome patients after hematopoietic cell transplantation: An international multicenter study. Blood 2015, 125, 2164-2172. [CrossRef]

26. White, K.K. Orthopaedic aspects of mucopolysaccharidoses. Rheumatology 2011, 50, 26-33. [CrossRef] [PubMed]

27. Schmidt, M.; Breyer, S.; Löbel, U.; Yarar, S.; Stücker, R.; Ullrich, K.; Müller, I.; Muschol, N. Musculoskeletal manifestations in mucopolysaccharidosis type i (Hurler syndrome) following hematopoietic stem cell transplantation. Orphanet J. Rare Dis. 2016, 11, 93. [CrossRef]

28. Schwartz, I.V.D.; Ribeiro, M.G.; Mota, J.G.; Toralles, M.B.P.; Correia, P.; Horovitz, D.; Santos, E.S.; Monlleo, I.L.; Fett-Conte, A.C.; Sobrinho, R.P.O.; et al. A clinical study of 77 patients with mucopolysaccharidosis type II. Acta Paediatr. Int. J. Paediatr. 2007, 96, 63-70. [CrossRef]

29. Thappa, D.; Singh, A.; Jaisankar, T.; Rao, R.; Ratnakar, C. Pebbling of the skin: A marker of Hunter's syndrome. Pediatr. Dermatol. 1998, 15, 370-373. [CrossRef]

30. Ochiai, T.; Suzuki, Y.; Kato, T.; Shichino, H.; Chin, M.; Mugishima, H.; Orii, T. Natural history of extensive Mongolian spots in mucopolysaccharidosis type II (Hunter syndrome): A survey among 52 Japanese patients. J. Eur. Acad. Dermatol. Venereol. 2007, 21, 1082-1085. [CrossRef] [PubMed]

31. Broomfield, A.; Sims, J.; Mercer, J.; Hensman, P.; Ghosh, A.; Tylee, K.; Stepien, K.M.; Oldham, A.; Prathivadi Bhayankaram, N.; Wynn, R.; et al. The evolution of pulmonary function in childhood onset Mucopolysaccharidosis type I. Mol. Genet. Metab. 2020, 132, 94-99. [CrossRef]

32. Keilmann, A.; Nakarat, T.; Bruce, I.A.; Molter, D.; Malm, G. Hearing loss in patients with mucopolysaccharidosis II: Data from HOS - The Hunter Outcome Survey. J. Inherit. Metab. Dis. 2012, 35, 343-353. [CrossRef]

33. Kampmann, C.; Beck, M.; Morin, I.; Loehr, J.P. Prevalence and characterization of cardiac involvement in hunter syndrome. J. Pediatr. 2011, 159, 327-331.e2. [CrossRef]

34. Rigante, D.; Segni, G. Cardiac Structural Involvement in Mucopolysaccharidoses. Cardiology 2002, 98, 18-20. [CrossRef]

35. Dangel, J.H. Cardiovascular changes in children with mucopolysaccharide storage diseases and related disorders- clinical and echocardiographic findings in 64 patients. Eur. J. Pediatr. 1998, 157, 534-538. [CrossRef]

36. Leal, G.N.; De Paula, A.C.; Leone, C.; Kim, C.A. Echocardiographic study of paediatric patients with mucopolysaccharidosis. Cardiol. Young 2010, 20, 254-261. [CrossRef]

37. Jiménez-Arredondo, R.E.; Brambila-Tapia, A.J.L.; Mercado-Silva, F.M.; Ortiz-Aranda, M.; Benites-Godinez, V.; Olmos-Garcíade-ALBA, G.; Figuera, L.E. Association between brain structural anomalies, electroencephalogram and history of seizures in Mucopolysaccharidosis type II (Hunter syndrome). Neurol. Sci. 2017, 38, 445-450. [CrossRef]

38. Eisengart, J.; Rudser, K.; Tolar, J.; Orchared, P.; Kivisto, T.; Ziegler, R.S.; Whitley, C.; Shapiro, E. Enzyme replacement is associated with better cognitive outcomes after transplant in Hurler syndrome. J. Pedatr. 2013, 162, 375-380. [CrossRef] [PubMed]

39. Shapiro, E.G.; Nestrasil, I.; Rudser, K.; Delaney, K.; Kovac, V.; Ahmed, A.; Yund, B.; Orchard, P.J.; Eisengart, J.; Niklason, G.R.; et al. Neurocognition across the spectrum of mucopolysaccharidosis type I: Age, severity, and treatment. Mol. Genet. Metab. 2015, 116, 61-68. [CrossRef] [PubMed] 
40. Clarke, L. Mucopolysaccharidosis Type I. In GeneReviews; Adam, M.P., Ardinger, H.H., Pagon, R.A., Wallace, S.E., Bean, L.J.H., Mirzaa, G., Eds.; University of Washington: Seattle, WA, USA, 2002.

41. Young, I.D.; Harper, P.S. Psychosocial problems in Hunter's syndrome. Child. Care. Health Dev. 1981, 7, 201-209. [CrossRef] [PubMed]

42. Holley, R.J.; Deligny, A.; Wei, W.; Watson, H.A.; Niñonuevo, M.R.; Dagälv, A.; Leary, J.A.; Bigger, B.W.; Kjellén, L.; Merry, C.L.R. Mucopolysaccharidosis type I, unique structure of accumulated heparan sulfate and increased N-sulfotransferase activity in mice lacking $\alpha$-L-iduronidase. J. Biol. Chem. 2011, 286, 37515-37524. [CrossRef] [PubMed]

43. Lin, H.Y.; Lo, Y.T.; Wang, T.J.; Huang, S.F.; Tu, R.Y.; Chen, T.L.; Lin, S.P.; Chuang, C.K. Normalization of glycosaminoglycanderived disaccharides detected by tandem mass spectrometry assay for the diagnosis of mucopolysaccharidosis. Sci. Rep. 2019, 9, 10755. [CrossRef]

44. Langereis, E.J.; van Vlies, N.; Church, H.J.; Geskus, R.B.; Hollak, C.E.M.; Jones, S.A.; Kulik, W.; van Lenthe, H.; Mercer, J.; Schreider, L.; et al. Biomarker responses correlate with antibody status in mucopolysaccharidosis type I patients on long-term enzyme replacement therapy. Mol. Genet. Metab. 2015, 114, 129-137. [CrossRef]

45. Zhang, H.; Wood, T.; Young, S.; Millington, D. A straightforward, quantitative ultra-performance liquid chromatography-tandem mass spectrometric method for heparan sulfate, dermatan sulfate and chondroitin sulfate in urine: An improved clinical screening test for the mucopolysaccharidoses. Mol. Genet. Metab. 2015, 114, 123-128. [CrossRef] [PubMed]

46. Auray-Blais, C.; Bhérer, P.; Gagnon, R.; Young, S.P.; Zhang, H.H.; An, Y.; Clarke, J.T.R.; Millington, D.S. Efficient analysis of urinary glycosaminoglycans by LC-MS/MS in mucopolysaccharidoses type I, II and VI. Mol. Genet. Metab. 2011, 102, 49-56. [CrossRef]

47. Tanaka, N.; Kida, S.; Kinoshita, M.; Morimoto, H.; Shibasaki, T.; Tachibana, K.; Yamamoto, R. Evaluation of cerebrospinal fluid heparan sulfate as a biomarker of neuropathology in a murine model of mucopolysaccharidosis type II using high-sensitivity LC/MS/MS. Mol. Genet. Metab. 2018, 125, 53-58. [CrossRef]

48. Menkovic, I.; Lavoie, P.; Boutin, M.; Auray-Blais, C. Distribution of heparan sulfate and dermatan sulfate in mucopolysaccharidosis type II mouse tissues pre- and post-enzyme-replacement therapy determined by UPLC-MS/MS. Bioanalysis 2019, 11, 727-740. [CrossRef] [PubMed]

49. Zhang, H.; Dickson, P.I.; Stiles, A.R.; Chen, A.H.; Le, S.Q.; McCaw, P.; Beasley, J.; Millington, D.S.; Young, S.P. Comparison of dermatan sulfate and heparan sulfate concentrations in serum, cerebrospinal fluid and urine in patients with mucopolysaccharidosis type I receiving intravenous and intrathecal enzyme replacement therapy. Clin. Chim. Acta 2020, 508, 179-184. [CrossRef] [PubMed]

50. Andrade, F.; Aldámiz-Echevarría, L.; Llarena, M.; Couce, M.L. Sanfilippo syndrome: Overall review. Pediatr. Int. 2015, 57, 331-338. [CrossRef] [PubMed]

51. Harmatz, P.R.; Shediac, R. Mucopolysaccharidosis VI: Pathophysiology, diagnosis and treatment. Front. Biosci. Landmark 2017, 22, 385-406. [CrossRef]

52. Lin, H.Y.; Lee, C.L.; Lo, Y.T.; Wang, T.J.; Huang, S.F.; Chen, T.L.; Wang, Y.S.; Niu, D.M.; Chuang, C.K.; Lin, S.P. The relationships between urinary glycosaminoglycan levels and phenotypes of mucopolysaccharidoses. Mol. Genet. Genomic Med. 2018, 6, 982-992. [CrossRef]

53. Tomatsu, S.; Gutierrez, M.A.; Ishimaru, T.; Peña, O.M.; Montaño, A.M.; Maeda, H.; Velez-Castrillon, S.; Nishioka, T.; Fachel, A.A.; Cooper, A.; et al. Heparan sulfate levels in mucopolysaccharidoses and mucolipidoses. J. Inherit. Metab. Dis. 2005, 28, 743-757. [CrossRef]

54. Coppa, G.V.; Gabrielli, O.; Zampini, L.; Maccari, F.; Mantovani, V.; Galeazzi, T.; Santoro, L.; Padella, L.; Marchesiello, R.L.; Galeotti, F.; et al. Mental retardation in mucopolysaccharidoses correlates with high molecular weight urinary heparan sulphate derived glucosamine. Metab. Brain Dis. 2015, 30, 1343-1348. [CrossRef] [PubMed]

55. Mashima, R.; Sakai, E.; Tanaka, M.; Kosuga, M.; Okuyama, T. The levels of urinary glycosaminoglycans of patients with attenuated and severe type of mucopolysaccharidosis II determined by liquid chromatography-tandem mass spectrometry. Mol. Genet. Metab. Reports 2016, 7, 87-91. [CrossRef]

56. Hendriksz, C.J.; Muenzer, J.; Burton, B.K.; Pan, L.; Wang, N.; Naimy, H.; Pano, A.; Barbier, A.J. A cerebrospinal fluid collection study in pediatric and adult patients with hunter syndrome. J. Inborn Errors Metab. Screen. 2015, 2015, 1-5. [CrossRef]

57. Bishop, J.R.; Schuksz, M.; Esko, J.D. Heparan sulphate proteoglycans fine-tune mammalian physiology. Nature 2007, 446, 1030-1037. [CrossRef] [PubMed]

58. Billings, P.C.; Pacifici, M. Interactions of signaling proteins, growth factors and other proteins with heparan sulfate: Mechanisms and mysteries. Connect. Tissue Res. 2015, 56, 272-280. [CrossRef] [PubMed]

59. Tanaka, Y.; Adams, D.H.; Shaw, S. Proteoglycans on endothelial cells present adhesion-inducing cytokines to leukocytes. Immunol. Today 1993, 14, 111-115. [CrossRef]

60. Celie, J.W.A.M.; Beelen, R.H.J.; Van Den Born, J. Heparan sulfate proteoglycans in extravasation: Assisting leukocyte guidance. Front. Biosci. 2009, 14, 4932-4949. [CrossRef] [PubMed]

61. Bigger, B.W.; Begley, D.J.; Virgintino, D.; Pshezhetsky, A.V. Anatomical changes and pathophysiology of the brain in mucopolysaccharidosis disorders. Mol. Genet. Metab. 2018, 125, 322-331. [CrossRef]

62. De Pasquale, V.; Pavone, L.M. Heparan sulfate proteoglycans: The sweet side of development turns sour in mucopolysaccharidoses. Biochim. Biophys. Acta Mol. Basis Dis. 2019, 1865, 165539. [CrossRef] 
63. Trowbridge, J.M.; Gallo, R.L. Dermatan sulfate: New functions from an old glycosaminoglycan. Glycobiology 2002, 12, 117-125. [CrossRef]

64. Fischer, J. Tilorone-induced lysosomal storage of glycosaminoglycans in cultured corneal fibroblasts: Biochemical and physicochemical investigations. Biochem. J. 1995, 312, 215-222. [CrossRef]

65. Prokopek, M. The tilorone-induced mucopolysaccharidosis in rats. Biochemical investigations. Biochem. Pharmacol. 1991, 42, 2187-2191. [CrossRef]

66. Lullmann-Rauch, R. Keratopathy in rats after treatment with tilorone. Graefe's Arch. Ophthalmol. 1986, 224, 377-383. [CrossRef] [PubMed]

67. Hein, L.; Lüllmann-Rauch, R. Mucopolysaccharidosis and lipidosis in rats treated with tilorone analogues. Toxicology 1989, 58, 145-154. [CrossRef]

68. Hochuli, M.; Wüthrich, K.; Steinmann, B. Two-dimensional NMR spectroscopy of urinary glycosaminoglycans from patients with different mucopolysaccharidoses. NMR Biomed. 2003, 16, 224-236. [CrossRef]

69. Fuller, M.; Chau, A.; Nowak, R.C.; Hopwood, J.J.; Meikle, P.J. A defect in exodegradative pathways provides insight into endodegradation of heparan and dermatan sulfates. Glycobiology 2006, 16, 318-325. [CrossRef]

70. Ramage, P.; Cummingham, W. Comparative structural studies of urinary glycosaminoglycans in the Hurler and Hunter Syndromes. Biochim. Biophys. Acta 1975, 411, 325-333. [CrossRef]

71. Lawrence, R.; Brown, J.R.; Al-Mafraji, K.; Lamanna, W.C.; Beitel, J.R.; Boons, G.; Esko, J.D.; Crawford, B.E. Disease-specific non-reducing end carbohydrate biomarkers for mucopolysaccharidoses. Nat. Chem. Biol. 2012, 8, 197-204. [CrossRef]

72. Wilkinson, F.L.; Holley, R.J.; Langford-Smith, K.J.; Badrinath, S.; Liao, A.; Langford-Smith, A.; Cooper, J.D.; Jones, S.A.; Wraith, J.E.; Wynn, R.F.; et al. Neuropathology in mouse models of mucopolysaccharidosis type I, IIIA and IIIB. PLoS ONE 2012, 7, e35787. [CrossRef] [PubMed]

73. Gleitz, H.F.; Liao, A.Y.; Cook, J.R.; Rowlston, S.F.; Forte, G.M.; D’Souza, Z.; O’Leary, C.; Holley, R.J.; Bigger, B.W. Brain-targeted stem cell gene therapy corrects mucopolysaccharidosis type II via multiple mechanisms. EMBO Mol. Med. 2018, 10, e8730. [CrossRef]

74. Wegrzyn, G.; Jakóbkiewicz-Banecka, J.; Narajczyk, M.; Wiśniewski, A.; Piotrowska, E.; Gabig-Cimińska, M.; Kloska, A.; SłomińskaWojewódzka, M.; Korzon-Burakowska, A.; Wegrzyn, A. Why are behaviors of children suffering from various neuronopathic types of mucopolysaccharidoses different? Med. Hypotheses 2010, 75, 605-609. [CrossRef]

75. Herndon, M.E.; Stipp, C.S.; Lander, A.D. Interactions of neural glycosaminoglycans and proteoglycans with protein ligands: Assessment of selectivity, heterogeneity and the participation of core proteins in binding. Glycobiology 1999, 9, 143-155. [CrossRef] [PubMed]

76. Matsuo, I.; Kimura-Yoshida, C. Extracellular distribution of diffusible growth factors controlled by heparan sulfate proteoglycans during mammalian embryogenesis. Philos. Trans. R. Soc. B Biol. Sci. 2014, 369, 20130545. [CrossRef] [PubMed]

77. Mertens, G.; Van Der Schueren, B.; Van Den Berghe, H.; David, G. Heparan sulfate expression in polarized epithelial cells: The apical sorting of glypican (GPI-anchored proteoglycan) is inversely related to its heparan sulfate content. J. Cell Biol. 1996, 132, 487-497. [CrossRef] [PubMed]

78. Afratis, N.; Gialeli, C.; Nikitovic, D.; Tsegenidis, T.; Karousou, E.; Theocharis, A.D.; Pavão, M.S.; Tzanakakis, G.N.; Karamanos, N.K. Glycosaminoglycans: Key players in cancer cell biology and treatment. FEBS J. 2012, 279, 1177-1197. [CrossRef]

79. Ohtsubo, K.; Marth, J.D. Glycosylation in Cellular Mechanisms of Health and Disease. Cell 2006, 126, 855-867. [CrossRef]

80. Watson, H.A.; Holley, R.J.; Langford-Smith, K.J.; Wilkinson, F.L.; Van Kuppevelt, T.H.; Wynn, R.F.; Wraith, J.E.; Merry, C.L.R.; Bigger, B.W. Heparan sulfate inhibits hematopoietic stem and progenitor cell migration and engraftment in mucopolysaccharidosis I. J. Biol. Chem. 2014, 289, 36194-36203. [CrossRef] [PubMed]

81. Gallagher, J.T. Multiprotein signalling complexes: Regional assembly on heparan sulphate. Biochem. Soc. Trans. 2006, 34, 438-441. [CrossRef]

82. Allen, B.L.; Filla, M.S.; Rapraeger, A.C. Role of heparan sulfate as a tissue-specific regulator of FGF-4 and FGF receptor recognition. J. Cell Biol. 2001, 155, 845-857. [CrossRef]

83. Brokowska, J.; Pierzynowska, K.; Gaffke, L.; Rintz, E.; Wegrzyn, G. Expression of genes involved in apoptosis is dysregulated in mucopolysaccharidoses as revealed by pilot transcriptomic analyses. Cell Biol. Int. 2021, 45, 549-557. [CrossRef] [PubMed]

84. Gaffke, L.; Pierzynowska, K.; Podlacha, M.; Hoinkis, D.; Rintz, E.; Brokowska, J.; Cyske, Z.; Wegrzyn, G. Underestimated aspect of mucopolysaccharidosis pathogenesis: Global changes in cellular processes revealed by transcriptomic studies. Int. J. Mol. Sci. 2020, 21, 1204. [CrossRef] [PubMed]

85. Salvalaio, M.; D'Avanzo, F.; Rigon, L.; Zanetti, A.; D'Angelo, M.; Valle, G.; Scarpa, M.; Tomanin, R. Brain RNA-seq profiling of the mucopolysaccharidosis type II mouse model. Int. J. Mol. Sci. 2017, 18, 1072. [CrossRef] [PubMed]

86. Heywood, W.E.; Camuzeaux, S.; Doykov, I.; Patel, N.; Preece, R.L.; Footitt, E.; Cleary, M.; Clayton, P.; Grunewald, S.; Abulhoul, L.; et al. Proteomic Discovery and Development of a Multiplexed Targeted MRM-LC-MS/MS Assay for Urine Biomarkers of Extracellular Matrix Disruption in Mucopolysaccharidoses I, II, and VI. Anal. Chem. 2015, 87, 12238-12244. [CrossRef]

87. Yuan, X.; Meng, Y.; Chen, C.; Liang, S.; Ma, Y.; Jiang, W.; Duan, J.; Wang, C. Proteomic approaches in the discovery of potential urinary biomarkers of mucopolysaccharidosis type II. Clin. Chim. Acta 2019, 499, 34-40. [CrossRef]

88. Ou, L.; Przybilla, M.; Whitley, C. Proteomic analysis of muccopolysaccharidosis I mouse brain with two-dimensional polyacrylamide gel electrophoresis. Mol. Genet. Metab. 2017, 120, 101-110. [CrossRef] 
89. Baldo, G.; Lorenzini, D.M.; Santos, D.S.; Mayer, F.Q.; Vitry, S.; Bigou, S.; Heard, J.M.; Matte, U.; Giugliani, R. Shotgun proteomics reveals possible mechanisms for cognitive impairment in Mucopolysaccharidosis I mice. Mol. Genet. Metab. 2015, 114, 138-145. [CrossRef]

90. Cardona, C.; Benincore, E.; Pimentel, N.; Reyes, L.H.; Patarroyo, C.; Rodríguez-López, A.; Rufián, M.M.; Barrera, L.A.; AlmécigaDíaz, C.J. Identification of the iduronate-2-sulfatase proteome in wild-type mouse brain. Heliyon 2019, 5, e01667. [CrossRef]

91. Lonergan, C.; Payne, A.; Wilson, W.; Patterson, J.; Englisch III, J. What syndrome is this? Pediatr. Dermatol. 2005, 22, 266-267. [CrossRef]

92. Prystowsky, S.D.; Maumenee, I.H.; Freeman, R.G.; Herndon, J.H.; Jo Harrod, M. A Cutaneous Marker in the Hunter Syndrome: A Report of Four Cases. Arch. Dermatol. 1977, 113, 602-605. [CrossRef]

93. Freeman, R.G. A Pathological Basis for the Cutaneous Papules of Mucopolysaccharidosis II (The Hunter Syndrome). J. Cutan. Pathol. 1977, 4, 318-328. [CrossRef]

94. Demitsu, T.; Kakurait, M.; Okubo, Y.; Shibayama, C.; Kikuchi, Y.; Mori, Y.; Sukegawa, K.; Mizuguchi, M. Skin eruption as the presenting sign of Hunter syndrome IIB. Clin. Exp. Dermatol. 1999, 24, 179-182. [CrossRef] [PubMed]

95. Warner, T.F.; Wrone, D.A.; Williams, E.C.; Cripps, D.J.; Mundhenke, C.F.A. Heparan sulphate proteoglycan in scleromyxedema promotes FGF-2 activity. Pathol Res. Pr. 2002, 198, 701-707. [CrossRef] [PubMed]

96. Cordova, A. The Mongolian Spot. Clin. Pediatr. 1981, 20, 714-719. [CrossRef] [PubMed]

97. Quantock, A.J.; Young, R.D. Development of the corneal stroma, and the collagen-proteoglycan associations that help define its structure and function. Dev. Dyn. 2008, 237, 2607-2621. [CrossRef] [PubMed]

98. Bredrup, C.; Knappskog, P.M.; Majewski, J.; Rødabi, E.; Boman, H. Congenital stromal dystrophy of the cornea caused by a mutation in the decorin gene. Investig. Ophthalmol. Vis. Sci. 2005, 46, 420-426. [CrossRef] [PubMed]

99. Rødahl, E.; Van Ginderdeuren, R.; Knappskog, P.M.; Bredrup, C.; Boman, H. A Second Decorin Frame Shift Mutation in a Family With Congenital Stromal Corneal Dystrophy. Am. J. Ophthalmol. 2006, 142, 520-521. [CrossRef]

100. Rühland, C.; Schönherr, E.; Robenek, H.; Hansen, U.; Iozzo, R.V.; Bruckner, P.; Seidler, D.G. The glycosaminoglycan chain of decorin plays an important role in collagen fibril formation at the early stages of fibrillogenesis. FEBS J. 2007, $274,4246-4255$. [CrossRef]

101. Mollard, R.; Telegan, P.; Haskins, M.; Aguirre, G. Corneal endothelium in mucopolysaccharide storage disorders. Morphologic studies in animal models. Cornea 1996, 15, 25-34. [CrossRef]

102. Fahnehjelm, K.T.; Ashworth, J.L.; Pitz, S.; Olsson, M.; Törnquist, A.L.; Lindahl, P.; Summers, C.G. Clinical guidelines for diagnosing and managing ocular manifestations in children with mucopolysaccharidosis. Acta Ophthalmol. 2012, 90, 595-602 [CrossRef]

103. Alroy, J.; Haskins, M.; Birk, D.E. Altered corneal stromal matrix organization is associated with mucopolysaccharidosis I, III and VI. Exp. Eye Res. 1999, 68, 523-530. [CrossRef]

104. Yuan, C.; Bothun, E.; Hardten, D.; Tolar, J.; McLoon, L. A novel explanation of corneal clouding in a bone marrow transplanttreated patient with Hurler syndrome. Exp. Eye Res. 2016, 148, 83-89. [CrossRef] [PubMed]

105. Levin, T.L.; Berdon, W.E.; Lachman, R.S.; Anyane-Yeboa, K.; Ruzal-Shapiro, C.; Roye, D.P. Lumbar gibbus in storage diseases and bone dysplasias. Pediatr. Radiol. 1997, 27, 289-294. [CrossRef] [PubMed]

106. Janecke, A.R.; Li, B.; Boehm, M.; Krabichler, B.; Rohrbach, M.; Müller, T.; Fuchs, I.; Golas, G.; Katagiri, Y.; Ziegler, S.G.; et al. The phenotype of the musculocontractural type of Ehlers-Danlos syndrome due to CHST14 mutations. Am. J. Med. Genet. Part A 2016, 107A, 103-115. [CrossRef]

107. Uehara, M.; Kosho, T.; Yamamoto, N.; Takahashi, H.E.; Shimakura, T.; Nakayama, J.; Kato, H.; Takahashi, J. Spinal manifestations in 12 patients with musculocontractural Ehlers-Danlos syndrome caused by CHST14/D4ST1 deficiency (mcEDS-CHST14). Am. J. Med. Genet. Part A 2018, 176, 2331-2341. [CrossRef]

108. Boffi, L.; Russo, P.; Limongelli, G. Early diagnosis and management of cardiac manifestations in mucopolysaccharidoses: A practical guide for paediatric and adult cardiologists. Ital. J. Pediatr. 2018, 44, 122. [CrossRef]

109. Braunlin, E.A.; Harmatz, P.R.; Scarpa, M.; Furlanetto, B.; Kampmann, C.; Loehr, J.P.; Ponder, K.P.; Roberts, W.C.; Rosenfeld, H.M.; Giugliani, R. Cardiac disease in patients with mucopolysaccharidosis: Presentation, diagnosis and management. J. Inherit. Metab. Dis. 2011, 34, 1183-1197. [CrossRef]

110. Azevedo, A.C.M.M.; Schwartz, I.V.; Kalakun, L.; Brustolin, S.; Burin, M.G.; Beheregaray, A.P.C.; Leistner, S.; Giugliani, C.; Rosa, M.; Barrios, P.; et al. Clinical and biochemical study of 28 patients with mucopolysaccharides type VI. Clin. Genet. 2004, 66, 208-213. [CrossRef] [PubMed]

111. Scarpa, M.; Barone, R.; Fiumara, A.; Astarita, L.; Parenti, G.; Rampazzo, A.; Sala, S.; Sorge, G.; Parini, R. Mucopolysaccharidosis VI: The Italian experience. Eur. J. Pediatr. 2009, 168, 1203-1206. [CrossRef]

112. Latif, N.; Sarathchandra, P.; Taylor, P.; Antoniw, J.; Yacoub, M. Localization and pattern of expression of extracellular matrix components in human heart valves. J. Hear. Valve Dis. 2005, 14, 218-227.

113. Dekaban, A.S.; Constantopoulos, G. Mucopolysaccharidosis types I, II, IIIA and V - Pathological and biochemical abnormalities in the neural and mesenchymal elements of the brain. Acta Neuropathol. 1977, 39, 1-7. [CrossRef] [PubMed]

114. Constantopoulos, G.; Iqbal, K.; Dekaban, A.S. Mucopolysaccharidosis Types IH, IS, II and IIIA: Glycosaminoglycans and Lipids of Isolated Brain Cells and Other Fractions from Autopsied Tissues. J. Neurochem. 1980, 34, 1399-1411. [CrossRef] [PubMed]

115. Lach, B.; Haust, M. Nodular lesions of choroid plexus in Hurler disease. Fetal Pediatr. Pathol. 2011, 30, 189-198. [CrossRef] 
116. Shapiro, E.; Nestrasil, I.; Delaney, K.A.; Rudser, K.; Kovac, V.; Nair, N.; Richard, C.I.; Haslett, P.; Whitley, C.B. A prospective natural history study of Mucopolysaccharidosis Type IIIA. J. Pediatr. 2016, 170, 278-287. [CrossRef] [PubMed]

117. Neufeld, E.; Muenzer, J. The Mucopolysaccharidoses, 8th ed.; Scriver, C., Beaudet, A., Sly, W., Valle, D., Childs, B., Kinzler, K., Vogelstein, B., Eds.; McGraw-Hill: New York, NY, USA, 2001.

118. Whitley, C.B.; Cleary, M.; Eugen Mengel, K.; Harmatz, P.; Shapiro, E.; Nestrasil, I.; Haslett, P.; Whiteman, D.; Alexanderian, D. Observational Prospective Natural History of Patients with Sanfilippo Syndrome Type B. J. Pediatr. 2018, 197, 198-206.e2. [CrossRef]

119. Nestrasil, I.; Vedolin, L. Quantitative neuroimaging in mucopolysaccharidoses clinical trials. Mol. Genet. Metab. 2017, 122, 17-24. [CrossRef] [PubMed]

120. King, K.E.; Rudser, K.D.; Nestrasil, I.; Kovac, V.; Delaney, K.A.; Wozniak, J.R.; Mueller, B.A.; Lim, K.O.; Eisengart, J.B.; Mamak, E.G.; et al. Attention and corpus callosum volumes in individuals with mucopolysaccharidosis type I. Neurology 2019, 92, E2321-E2328. [CrossRef] [PubMed]

121. Yund, B.; Rudser, K.; Ahmed, A.; Kovac, V.; Nestrasil, I.; Raiman, J.; Mamak, E.; Harmatz, P.; Steiner, R.; Lau, H.; et al. Cognitive, medical, and neuroimaging characteristics of attenuated mucopolysaccharidosis type II. Mol. Genet. Metab. 2015, 114, 170-177. [CrossRef]

122. Shapiro, E.; Guler, O.E.; Rudser, K.; Delaney, K.; Bjoraker, K.; Whitley, C.; Tolar, J.; Orchard, P.; Provenzale, J.; Thomas, K.M. An exploratory study of brain function and structure in mucopolysaccharidosis type I: Long term observations following hematopoietic cell transplantation (HCT). Mol. Genet. Metab. 2012, 107, 116-121. [CrossRef]

123. Cross, E.M.; Hare, D.J. Behavioural phenotypes of the mucopolysaccharide disorders: A systematic literature review of cognitive, motor, social, linguistic and behavioural presentation in the MPS disorders. J. Inherit. Metab. Dis. 2013, 36, 189-200. [CrossRef]

124. Shapiro, E.G.; Whitley, C.B.; Eisengart, J.B. Beneath the floor: Re-analysis of neurodevelopmental outcomes in untreated Hurler syndrome. Orphanet J. Rare Dis. 2018, 13, 76. [CrossRef]

125. Ahmed, A.; Shapiro, E.; Rudser, K.; Kunin-Batson, A.; King, K.; Whitley, C.B. Association of somatic burden of disease with age and neuropsychological measures in attenuated mucopolysaccharidosis types I, II and VI. Mol. Genet. Metab. Reports 2016, 7, 27-31. [CrossRef]

126. Ahmed, A.; Whitley, C.B.; Cooksley, R.; Rudser, K.; Cagle, S.; Ali, N.; Delaney, K.; Yund, B.; Shapiro, E. Neurocognitive and neuropsychiatric phenotypes associated with the mutation L238Q of the alpha-L-iduronidase gene in Hurler-Scheie syndrome. Mol. Genet. Metab. 2014, 111, 123-127. [CrossRef]

127. Bax, M.C.O.; Colville, G.A. Behaviour in mucopolysaccharide disorders. Arch. Dis. Child. 1995, 73, 77-81. [CrossRef]

128. Shapiro, E.G.; Escolar, M.L.; Delaney, K.A.; Mitchell, J.J. Assessments of neurocognitive and behavioral function in the mucopolysaccharidoses. Mol. Genet. Metab. 2017, 122, 8-16. [CrossRef] [PubMed]

129. Potegal, M.; Yund, B.; Rudser, K.; Ahmed, A.; Delaney, K.; Nestrasil, I.; Whitley, C.B.; Shapiro, E.G. Mucopolysaccharidosis Type IIIA presents as a variant of Klüver-Bucy syndrome. J. Clin. Exp. Neuropsychol. 2013, 35, 608-616. [CrossRef] [PubMed]

130. King, K.; Shapiro, E.; Rudser, K.; Whitley, C. Emotional-behavioral functioning in individuals with MPS I: A longitudinal approach. Mol. Genet. Metab. 2016, 2, S67-S68. [CrossRef]

131. Staba, S.L.; Escolar, M.L.; Poe, M.; Kim, Y.; Martin, P.L.; Szabolcs, P.; Allison-Thacker, J.; Wood, S.; Wenger, D.A.; Rubinstein, P.; et al. Cord-blood transplants from unrelated donors in patients with Hurler's syndrome. N. Engl. J. Med. 2004, 350, 1960-1969. [CrossRef]

132. Seto, T.; Kono, K.; Morimoto, K.; Inoue, Y.; Shintaku, H.; Hattori, H.; Matsuoka, O.; Yamano, T.; Tanaka, A. Brain magnetic resonance imaging in 23 patients with mucopolysaccharidoses and the effect of bone marrow transplantation. Ann. Neurol. 2001, 50, 79-92. [CrossRef] [PubMed]

133. Guffon, N.; Pettazzoni, M.; Pangaud, N.; Garin, C.; Lina-Granade, G.; Plault, C.; Mottolese, C.; Froissart, R.; Fouilhoux, A. Long term disease burden post-transplantation: Three decades of observations in 25 Hurler patients successfully treated with hematopoietic stem cell transplantation (HSCT). Orphanet J. Rare Dis. 2021, 16, 60. [CrossRef]

134. Grant, N. Evaluating strategies to manage and endure challenging behaviors in mucopolysaccharidoses. Orphanet J. Rare Dis. 2021, 16, 165. [CrossRef] [PubMed]

135. Holt, J.; Poe, M.D.; Escolar, M.L. Early clinical markers of central nervous system involvement in mucopolysaccharidosis type II. J. Pediatr. 2011, 159, 320-326.e2. [CrossRef] [PubMed]

136. Eisengart, J.B.; King, K.E.; Shapiro, E.G.; Whitley, C.B.; Muenzer, J. The nature and impact of neurobehavioral symptoms in neuronopathic Hunter syndrome. Mol. Genet. Metab. Reports 2020, 22, 100549. [CrossRef]

137. Roberts, J.; Stewart, C.; Kearney, S. Management of the behavioural manifestations of hunter syndrome. Br. J. Nurs. 2016, 25, 22-30. [CrossRef]

138. Scarpa, M.; Lourenço, C.M.; Amartino, H. Epilepsy in mucopolysaccharidosis disorders. Mol. Genet. Metab. 2017, 122, 55-61. [CrossRef]

139. Kuzenkova, L.; Podkletnova, T.; Namazova-Baranova, L.; Gevorkya, A.; Vashakmadze, N.; Zhurkova, N.; Nechaeva, N. Particular features of neurological symptoms with children suffering from MPS syndrome type II. Mol. Genet. Metab. 2013, 108, S56-S57. [CrossRef]

140. Young, I.D.; Harper, P.S. Mild form of Hunter's syndrome: Clinical delineation based on 31 cases. Arch. Dis. Child. 1982, 57, 828-836. [CrossRef] [PubMed] 
141. Inatani, M.; Irie, F.; Plump, A.S.; Tessier-Lavigne, M.; Yamaguchi, Y. Mammalian Brain Morphogenesis and Midline Axon Guidance Require Heparan Sulfate. Science 2003, 302, 1044-1046. [CrossRef]

142. Poulain, F.E.; Joseph Yost, H. Heparan sulfate proteoglycans: A sugar code for vertebrate development? Development 2015, 142, 3456-3467. [CrossRef] [PubMed]

143. Pan, C.; Nelson, M.S.; Reyes, M.; Koodie, L.; Brazil, J.J.; Stephenson, E.J.; Zhao, R.C.; Peters, C.; Selleck, S.B.; Stringer, S.E.; et al. Functional abnormalities of heparan sulfate in mucopolysaccharidosis-I are associated with defective biologic activity of FGF-2 on human multipotent progenitor cells. Blood 2005, 106, 1956-1964. [CrossRef]

144. Fuller, M.; Brooks, D.A.; Evangelista, M.; Hein, L.K.; Hopwood, J.J.; Meikle, P.J. Prediction of neuropathology in mucopolysaccharidosis I patients. Mol. Genet. Metab. 2005, 84, 18-24. [CrossRef]

145. Jastrebova, N.; Vanwildemeersch, M.; Lindahl, U.; Spillmann, D. Heparan sulfate domain organization and sulfation modulate FGF-induced cell signaling. J. Biol. Chem. 2010, 285, 26842-26851. [CrossRef] [PubMed]

146. Simonaro, C.M.; Ge, Y.; Eliyahu, E.; He, X.; Jepsen, K.J.; Schuchman, E.H. Involvement of the Toll-like receptor 4 pathway and use of TNF- $\alpha$ antagonists for treatment of the mucopolysaccharidoses. Proc. Natl. Acad. Sci. USA 2010, 107, 222-227. [CrossRef]

147. Goodall, K.J.; Poon, I.K.H.; Phipps, S.; Hulett, M.D. Soluble heparan sulfate fragments generated by heparanase trigger the release of pro-inflammatory cytokines through TLR-4. PLoS ONE 2014, 9, e109596. [CrossRef]

148. O'Callaghan, P.; Zhang, X.; Li, J.P. Heparan Sulfate Proteoglycans as Relays of Neuroinflammation. J. Histochem. Cytochem. 2018, 66, 305-319. [CrossRef] [PubMed]

149. Lloyd-Evans, E.; Haslett, L.J. The lysosomal storage disease continuum with ageing-related neurodegenerative disease. Ageing Res. Rev. 2016, 32, 104-121. [CrossRef]

150. Snow, A.D.; Mar, H.; Nochlin, D.; Sekiguchi, R.T.; Kimata, K.; Koike, Y.; Wight, T.N. Early accumulation of heparan sulfate in neurons and in the beta-amyloid protein-containing lesions of Alzheimer's disease and Down's syndrome. Am. J. Pathol. 1990, 137, 1253-1270. [CrossRef]

151. Holmes, B.B.; DeVos, S.L.; Kfoury, N.; Li, M.; Jacks, R.; Yanamandra, K.; Ouidja, M.O.; Brodsky, F.M.; Marasa, J.; Bagchi, D.P.; et al. Heparan sulfate proteoglycans mediate internalization and propagation of specific proteopathic seeds. Proc. Natl. Acad. Sci. USA 2013, 110, e3138-e3147. [CrossRef] [PubMed]

152. Maïza, A.; Chantepie, S.; Vera, C.; Fifre, A.; Huynh, M.B.; Stettler, O.; Ouidja, M.O.; Papy-Garcia, D. The role of heparan sulfates in protein aggregation and their potential impact on neurodegeneration. FEBS Lett. 2018, 592, 3806-3818. [CrossRef] [PubMed]

153. Walkley, S.U. Secondary accumulation of gangliosides in lysosomal storage disorders. Semin. Cell Dev. Biol. 2004, 15, 433-444. [CrossRef]

154. Walkley, S.U.; Vanier, M. Secondary lipid accumulation in lysosomal disease. Biochim. Biophys. Acta 2009, 1793, 726-736. [CrossRef]

155. Viana, G.M.; Priestman, D.A.; Platt, F.M.; Khan, S.; Tomatsu, S.; Pshezhetsky, A.V. Brain Pathology in Mucopolysaccharidoses (MPS) Patients with Neurological Forms. J. Clin. Med. 2020, 9, 396. [CrossRef]

156. McGlynn, R.; Dobrenis, K.; Walkley, S.U. Differential subcellular localization of cholesterol, gangliosides, and glycosaminoglycans in murine models of mucopolysaccharide storage disorders. J. Comp. Neurol. 2004, 480, 415-426. [CrossRef]

157. Hampe, C.S.; Polgreen, L.E.; Lund, T.C.; McIvor, R.S. Dysostosis Multiplex in Human Mucopolysaccharidosis Type $1 \mathrm{H}$ and in Animal Models of the Disease. Pediatr. Endocrinol. Rev. 2020, 17, 317-326. [CrossRef]

158. Wilkerson, M.; Lewis, D.; Marks, S.; Prieur, D. Syndrome, Clinical and Morphologic Features of Mucopolysaccharidosis Type II in a Dog: Naturally Occurring Model of Hunter Syndrome. Vet. Pathol. 1998, 35, 230-233. [CrossRef]

159. Muenzer, J.; Lamsa, J.C.; Garcia, A.; Dacosta, J.; Garcia, J.; Treco, D.A. Enzyme replacement therapy in mucopolysaccharidosis type II (Hunter syndrome): A preliminary report. Acta Paediatr. Suppl. 2002, 91, 98-99. [CrossRef]

160. Hinderer, C.; Katz, N.; Louboutin, J.P.; Bell, P.; Yu, H.; Nayal, M.; Kozarsky, K.; O’Brien, W.T.; Goode, T.; Wilson, J.M. Delivery of an Adeno-associated virus vector into cerebrospinal fluid attenuates central nervous system disease in mucopolysaccharidosis type II mice. Hum. Gene Ther. 2016, 27, 906-915. [CrossRef]

161. Higuchi, T.; Shimizu, H.; Fukuda, T.; Kawagoe, S.; Matsumoto, J.; Shimada, Y.; Kobayashi, H.; Ida, H.; Ohashi, T.; Morimoto, H.; et al. Enzyme replacement therapy (ERT) procedure for mucopolysaccharidosis type II (MPS II) by intraventricular administration (IVA) in murine MPS II. Mol. Genet. Metab. 2012, 107, 122-128. [CrossRef]

162. Jung, S.C.; Park, E.S.; Choi, E.N.; Kim, C.H.; Kim, S.J.; Jin, D.K. Characterization of a novel mucopolysaccharidosis type II mouse model and recombinant AAV2/8 vector-mediated gene therapy. Mol. Cells 2010, 30, 13-18. [CrossRef]

163. Hong, S.H.; Chu, H.; Kim, K.R.; Ko, M.H.; Kwon, S.Y.; Moon, I.J.; Chung, W.H.; Cho, Y.S.; Kim, C.H.; Suh, M.W.; et al. Auditory characteristics and therapeutic effects of enzyme replacement in mouse model of the mucopolysaccharidosis (MPS) II. Am. J. Med. Genet. Part A 2012, 158 A, 2131-2138. [CrossRef]

164. Garcia, A.R.; Pan, J.; Lamsa, J.C.; Muenzer, J. The characterization of a murine model of mucopolysaccharidosis II (Hunter syndrome). J. Inherit. Metab. Dis. 2007, 30, 924-934. [CrossRef]

165. Friso, A.; Tomanin, R.; Alba, S.; Gasparotto, N.; Puicher, E.P.; Fusco, M.; Hortelano, G.; Muenzer, J.; Marin, O.; Zacchello, F.; et al. Reduction of GAG storage in MPS II mouse model following implantation on encapsulated recombinant myoblasts. J. Gene Med. 2005, 7, 1482-1491. [CrossRef]

166. Cardone, M.; Polito, V.A.; Pepe, S.; Mann, L.; D’Azzo, A.; Auricchio, A.; Ballabio, A.; Cosma, M.P. Correction of Hunter syndrome in the MPSII mouse model by AAV2/8-mediated gene delivery. Hum. Mol. Genet. 2006, 15, 1225-1236. [CrossRef] 
167. Wakabayashi, T.; Shimada, Y.; Akiyama, K.; Higuchi, T.; Fukuda, T.; Kobayashi, H.; Eto, Y.; Ida, H.; Ohashi, T. Hematopoietic Stem Cell Gene Therapy Corrects Neuropathic Phenotype in Murine Model of Mucopolysaccharidosis Type II. Hum. Gene Ther. 2015, 26, 357-366. [CrossRef]

168. Polito, V.A.; Abbondante, S.; Polishchuk, R.S.; Nusco, E.; Salvia, R.; Cosma, M.P. Correction of CNS defects in the MPSII mouse model via systemic enzyme replacement therapy. Hum. Mol. Genet. 2010, 19, 4871-4885. [CrossRef]

169. Motas, S.; Haurigot, V.; Garcia, M.; Marcó, S.; Ribera, A.; Roca, C.; Sánchez, X.; Sánchez, V.; Molas, M.; Bertolin, J.; et al. CNS-directed gene therapy for the treatment of neurologic and somatic mucopolysaccharidosis type II (Hunter syndrome). JCI Insight 2016, 1, e86696. [CrossRef]

170. Provoost, L.; Siracusa, C.; Stefanovski, D.; Che, Y.; Li, M.; Casal, M. Cognitive abilities of dogs with mucopolysaccharidosis I: Learning and memory. Animals 2020, 10, 397. [CrossRef]

171. Shull, R.; Munger, R.; Spellacy, E.; Hall, C.; Constantopoulos, G.C.; Neufeld, E.F. Canine alpha-L-Iduronidase Deficiency A Model of Mucopolysaccharidosis I. Am. J. Pathol. 1982, 109, 244-248. [PubMed]

172. Spellacy, E.; Shull, R.M.; Constantopoulos, G.; Neufeld, E.F. A canine model of human $\alpha$-L-iduronidase deficiency. Proc. Natl. Acad. Sci. USA 1983, 80, 6091-6095. [CrossRef] [PubMed]

173. Wang, D.; Shukla, C.; Liu, X.; Schoeb, T.R.; Clarke, L.A.; Bedwell, D.M.; Keeling, K.M. Characterization of an MPS I-H knock-in mouse that carries a nonsense mutation analogous to the human IDUA-W402X mutation. Mol. Genet. Metab. 2010, 99, 62-71. [CrossRef] [PubMed]

174. Oestreich, A.K.; Garcia, M.R.; Yao, X.; Pfeiffer, F.M.; Nobakhti, S.; Shefelbine, S.J.; Wang, Y.; Brodeur, A.C.; Phillips, C.L. Characterization of the MPS I-H knock-in mouse reveals increased femoral biomechanical integrity with compromised material strength and altered bone geometry. Mol. Genet. Metab. Rep. 2015, 5, 3-11. [CrossRef]

175. Galimberti, C.; Madeo, A.; Di Rocco, M.; Fiumara, A. Mucopolysaccharidoses: Early diagnostic signs in infants and children. Ital. J. Pediatr. 2018, 44, 133. [CrossRef]

176. Aldenhoven, M.; Boelens, J.; de Koning, T.J. The Clinical Outcome of Hurler Syndrome after Stem Cell Transplantation. Biol. Blood Marrow Transplant. 2008, 14, 485-498. [CrossRef]

177. Barone, R.; Pellico, A.; Pittalà, A.; Gasperini, S. Neurobehavioral phenotypes of neuronopathic mucopolysaccharidoses. Ital. J. Pediatr. 2018, 44, 121. [CrossRef]

178. Shapiro, E.G.; Lockman, L.A.; Balthazor, M.; Krivit, W. Neuropsychological outcomes of several storage diseases with and without bone marrow transplantation. J. Inherit. Metab. Dis. 1995, 18, 413-429. [CrossRef]

179. Seo, J.H.; Okuyama, T.; Shapiro, E.; Fukuhara, Y.; Kosuga, M. Natural history of cognitive development in neuronopathic mucopolysaccharidosis type II (Hunter syndrome): Contribution of genotype to cognitive developmental course. Mol. Genet. Metab. Rep. 2020, 24, 100630. [CrossRef] [PubMed]

180. Parini, R.; Jones, S.A.; Harmatz, P.R.; Giugliani, R.; Mendelsohn, N.J. The natural history of growth in patients with Hunter syndrome: Data from the Hunter Outcome Survey (HOS). Mol. Genet. Metab. 2016, 117, 438-446. [CrossRef]

181. Colville, G.A.; Bax, M.A. Early presentation in the mucopolysaccharide disorders. Child. Care. Health Dev. 1996, $22,31-36$. [CrossRef] [PubMed]

182. Pan, D.; Sciascia, A.; Vorhees, C.V.; Williams, M.T. Progression of multiple behavioral deficits with various ages of onset in a murine model of Hurler syndrome. Brain Res. 2008, 1188, 241-253. [CrossRef] [PubMed]

183. Baldo, G.; Mayer, F.Q.; Martinelli, B.Z.; de Carvalho, T.G.; Meyer, F.S.; de Oliveira, P.G.; Meurer, L.; Tavares, Â.; Matte, U.; Giugliani, R. Enzyme replacement therapy started at birth improves outcome in difficult-to-treat organs in mucopolysaccharidosis I mice. Mol. Genet. Metab. 2013, 109, 33-40. [CrossRef]

184. Clarke, L.A.; Russell, C.S.; Pownall, S.; Warrington, C.L.; Borowski, A.; Dimmick, J.E.; Toone, J.; Jirik, F.R. Murine mucopolysaccharidosis type I: Targeted disruption of the murine alpha-L-iduronidase gene. Hum. Mol. Genet. 1997, 6, 503-511. [CrossRef] [PubMed]

185. Gleitz, H.F.E.; O'Leary, C.; Holley, R.J.; Bigger, B.W. Identification of age-dependent motor and neuropsychological behavioural abnormalities in a mouse model of mucopolysaccharidosis type II. PLoS ONE 2017, 12, e0172435. [CrossRef] [PubMed]

186. Schachern, P.A.; Shea, D.A.; Paparella, M.M. Mucopolysaccharidosis I-H (Hurler's syndrome) and human temporal bone histopathology. Ann. Otol. Rhinol. Laryngol. 1984, 93, 65-69. [CrossRef] [PubMed]

187. Gomez-Ospina, N.; Scharenberg, S.G.; Mostrel, N.; Bak, R.O.; Mantri, S.; Quadros, R.M.; Gurumurthy, C.B.; Lee, C.; Bao, G.; Suarez, C.J.; et al. Human genome-edited hematopoietic stem cells phenotypically correct Mucopolysaccharidosis type I. Nat. Commun. 2019, 10, 4045. [CrossRef] [PubMed]

188. Hampe, C.S.; Wesley, J.; Lund, T.C.; Orchard, P.J.; Polgreen, L.E.; Eisengart, J.B.; McLoon, L.K.; Cureoglu, S.; Schachern, P.; McIvor, R.S. Mucopolysaccharidosis type I: Current treatments, limitations and prospects for improvement. Biomolecules 2021, 11, 189. [CrossRef]

189. Parini, R.; Deodato, F.; Di Rocco, M.; Lanino, E.; Locatelli, F.; Messina, C.; Rovelli, A.; Scarpa, M. Open issues in Mucopolysaccharidosis type I-Hurler. Orphanet J. Rare Dis. 2017, 12, 112. [CrossRef]

190. Chung, Y.K.; Sohn, Y.B.; Sohn, J.M.; Lee, J.J.Y.; Chang, M.S.; Kwun, Y.; Kim, C.H.; Lee, J.J.Y.; Yook, Y.J.; Ko, A.-R.; et al. A biochemical and physicochemical comparison of two recombinant enzymes used for enzyme replacement therapies of hunter syndrome. Glycoconj. J. 2014, 31, 309-315. [CrossRef] 
191. Burton, B.K.; Jego, V.; Mikl, J.; Jones, S.A. Survival in idursulfase-treated and untreated patients with mucopolysaccharidosis type II: Data from the Hunter Outcome Survey (HOS). J. Inherit. Metab. Dis. 2017, 40, 867-874. [CrossRef]

192. Wikman-Jorgensen, P.E.; López Amorós, A.; Peris García, J.; Esteve Atienzar, P.J.; Cañizares Navarro, R.; Asensio Tomás, M.L.; Seguí Ripoll, J.M.; Bonet, D.; Esteban-Giner, M.J.; Robert, J.; et al. Enzyme replacement therapy for the treatment of Hunter disease: A systematic review with narrative synthesis and meta-analysis. Mol. Genet. Metab. 2020, 131, 206-210. [CrossRef]

193. Whiteman, D.; Kimura, A. Development of idursulfase therapy for mucopolysaccharidosis type II (Hunter syndrome): The past, the present and the future. Drug Des. Devel. Ther. 2017, 11, 2467-2480. [CrossRef]

194. Burrow, T.A.; Hopkin, R.J.; Leslie, N.D.; Tinkle, B.T.; Grabowski, G.A. Enzyme reconstitution/replacement therapy for lysosomal storage diseases. Curr. Opin. Pediatr. 2007, 19, 628-635. [CrossRef] [PubMed]

195. Sohn, Y.B.; Cho, S.Y.; Park, S.W.; Kim, S.J.; Ko, A.-R.; Kwon, E.-K.; Han, S.J.; Jin, D.-K. Phase I/II clinical trial of enzyme replacement therapy with idursulfase beta in patients with mucopolysaccharidosis II (Hunter syndrome). Orphanet J. Rare Dis 2013, 8, 42. [CrossRef] [PubMed]

196. Bhalla, A.; Ravi, R.; Fang, M.; Arguello, A.; Davis, S.S.; Chiu, C.L.; Blumenfeld, J.R.; Nguyen, H.N.; Earr, T.K.; Wang, J.; et al. Characterization of fluid biomarkers reveals lysosome dysfunction and neurodegeneration in neuronopathic MPS II patients. Int. J. Mol. Sci. 2020, 21, 5188. [CrossRef] [PubMed]

197. Parini, R.; Deodato, F. Intravenous enzyme replacement therapy in mucopolysaccharidoses: Clinical effectiveness and limitations. Int. J. Mol. Sci. 2020, 21, 2975. [CrossRef] [PubMed]

198. Barth, A.L.; de Magalhães, T.S.P.C.; Reis, A.B.R.; de Oliveira, M.L.; Scalco, F.B.; Cavalcanti, N.C.; Silva, D.S.E.; Torres, D.A.; Costa, A.A.P.; Bonfim, C.; et al. Early hematopoietic stem cell transplantation in a patient with severe mucopolysaccharidosis II: A 7 years follow-up. Mol. Genet. Metab. Rep. 2017, 12, 62-68. [CrossRef]

199. Tajima, G.; Sakura, N.; Kosuga, M.; Okuyama, T.; Kobayashi, M. Effects of idursulfase enzyme replacement therapy for Mucopolysaccharidosis type II when started in early infancy: Comparison in two siblings. Mol. Genet. Metab. 2013, 108, 172-177. [CrossRef]

200. Muenzer, J.; Gucsavas-Calikoglu, M.; McCandless, S.E.; Schuetz, T.J.; Kimura, A. A phase I/II clinical trial of enzyme replacement therapy in mucopolysaccharidosis II (Hunter syndrome). Mol. Genet. Metab. 2007, 90, 329-337. [CrossRef]

201. Muenzer, J.; Bodamer, O.; Burton, B.; Clarke, L.; Frenking, G.S.; Giugliani, R.; Jones, S.; Rojas, M.V.M.; Scarpa, M.; Beck, M.; et al. The role of enzyme replacement therapy in severe Hunter syndrome-an expert panel consensus. Eur. J. Pediatr. 2012, 171, 181-188. [CrossRef] [PubMed]

202. Muenzer, J.; Beck, M.; Eng, C.M.; Giugliani, R.; Harmatz, P.; Martin, R.; Ramaswami, U.; Vellodi, A.; Wraith, J.E.; Cleary, M.; et al. Long-term, open-labeled extension study of idursulfase in the treatment of Hunter syndrome. Genet. Med. 2011, 13, 95-101. [CrossRef]

203. Muhlebach, M.S.; Wooten, W.; Muenzer, J. Respiratory Manifestations in Mucopolysaccharidoses. Paediatr. Respir. Rev. 2011, 12, 133-138. [CrossRef]

204. Parini, R.; Rigoldi, M.; Tedesco, L.; Boffi, L.; Brambilla, A.; Bertoletti, S.; Boncimino, A.; Del Longo, A.; De Lorenzo, P.; Gaini, R.; et al. Enzymatic replacement therapy for Hunter disease: Up to 9 years experience with 17 patients. Mol. Genet. Metab. Rep. 2015, 3, 65-74. [CrossRef]

205. Lampe, C.; Bosserhoff, A.-K.; Burton, B.K.; Giugliani, R.; de Souza, C.F.; Bittar, C.; Muschol, N.; Olson, R.; Mendelsohn, N.J. Long-term experience with enzyme replacement therapy (ERT) in MPS II patients with a severe phenotype: An international case series. J. Inherit. Metab. Dis. 2014, 37, 823-829. [CrossRef]

206. Wang, J.; Luan, Z.; Jiang, H.; Fang, J.; Qin, M.; Lee, V.; Chen, J. Allogeneic Hematopoietic Stem Cell Transplantation in Thirty-Four Pediatric Cases of Mucopolysaccharidosis-A Ten-Year Report from the China Children Transplant Group. Biol. Blood Marrow Transplant. 2016, 22, 2104-2108. [CrossRef] [PubMed]

207. Suzuki, Y.; Taylor, M.; Orii, K.; Fukao, T.; Orii, T.; Tomatsu, S. Assessment of activity of daily life in mucopolysaccharidosis type II patients with hematopoietic stem cell transplantation. Diagnostics 2020, 10, 46. [CrossRef] [PubMed]

208. McKinnis, E.J.R.; Sulzbacher, S.; Rutledge, J.C.; Sanders, J.; Scott, C.R. Bone marrow transplantation in Hunter syndrome. J. Pediatr. 1996, 129, 145-148. [CrossRef]

209. Guffon, N.; Bertrand, Y.; Forest, I.; Fouilhoux, A.; Froissart, R. Bone Marrow Transplantation in Children with Hunter Syndrome: Outcome after 7 to 17 Years. J. Pediatr. 2009, 154, 733-737. [CrossRef]

210. Annibali, R.; Caponi, L.; Morganti, A.; Manna, M.; Gabrielli, O.; Ficcadenti, A. Hunter syndrome (Mucopolysaccharidosis type II), severe phenotype: Long term follow-up on patients undergone to hematopoietic stem cell transplantation. Minerva Pediatr. 2013, 65, 487-496. [PubMed]

211. Jones, S.A.; Parini, R.; Harmatz, P.; Giugliani, R.; Fang, J.; Mendelsohn, N.J. The effect of idursulfase on growth in patients with Hunter syndrome: Data from the Hunter Outcome Survey (HOS). Mol. Genet. Metab. 2013, 109, 41-48. [CrossRef]

212. Patel, P.; Suzuki, Y.; Tanaka, A.; Yabe, H.; Kato, S.; Shimada, T.; Mason, R.W.; Orii, K.E.; Fukao, T.; Orii, T.; et al. Impact of enzyme replacement therapy and hematopoietic stem cell therapy on growth in patients with Hunter syndrome. Mol. Genet. Metab. Rep. 2014, 1, 184-196. [CrossRef]

213. Coppa, G.V.; Gabrielli, O.; Zampini, L.; Pierani, P.; Giorgi, P.; Jezequel, A.; Orlandi, F.; Miniero, R.; Busca, A.; De Tuca, T. Bone marrow transplantation in Hunter syndrome (mucopolysaccharidosis type II): Two-year follow-up of the first Italian patient and review of the literature. Pediatr. Med. Chir. 1995, 17, 227-235. [PubMed] 
214. Imaizumi, M.; Gushi, K.; Kurobane, I.; Inoue, S.; Suzuki, J.; Koizumi, Y.; Suzuki, H.; Sato, A.; Gotoh, Y.-I.; Haginoya, K.; et al. Long-term effects of bone marrow transplantation for inborn errors. Acta Paediatr. Jpn. 1994, 36, 30-36. [CrossRef] [PubMed]

215. Tanaka, A.; Okuyama, T.; Suzuki, Y.; Sakai, N.; Takakura, H.; Sawada, T.; Tanaka, T.; Otomo, T.; Ohashi, T.; Ishige-Wada, M.; et al. Long-term efficacy of hematopoietic stem cell transplantation on brain involvement in patients with mucopolysaccharidosis type II: A nationwide survey in Japan. Mol. Genet. Metab. 2012, 107, 513-520. [CrossRef]

216. Bergstrom, S.; Quinn, J.; Greenstein, R.; Ascensao, J. Long-term follow-up of a patient transplanted for Hunter's disease type IIB: A case report and literature review. Bone Marrow Transpl. 1994, 14, 653-658.

217. Selvanathan, A.; Ellaway, C.; Wilson, C.; Owens, P.; Shaw, P.; Bhattacharya, K. Effectiveness of Early Hematopoietic Stem Cell Transplantation in Preventing Neurocognitive Decline in Mucopolysaccharidosis Type II: A Case Series. JIMD Rep. 2018, 41, 81-89. [CrossRef]

218. Warkentin, P.; Dixon, M.; Schafer, I.; Strandjord, S.; Coccia, P. Bone marrow transplantation in Hunter syndrome: A preliminary report. Birth Defects Orig Artic Ser 1986, 22, 31-39.

219. Li, P.; Thompson, J.N.; Hug, G.; Huffman, P.; Chuck, G. Biochemical and Molecular Analysis in a Patient with the Severe Form of Hunter Syndrome after Bone Marrow Transplantation. Am. J. Med. Genet. Semin. Med. Genet. 1996, 64, 531-535. [CrossRef]

220. Kubaski, F.; Yabe, H.; Suzuki, Y.; Seto, T.; Hamazaki, T.; Mason, R.W.; Xie, L.; Onsten, T.G.H.; Leistner-Segal, S.; Giugliani, R.; et al. Hematopoietic Stem Cell Transplantation for Patients with Mucopolysaccharidosis II. Biol. Blood Marrow Transplant. 2017, 23, 1795-1803. [CrossRef] [PubMed]

221. Noh, H.; Lee, J.I. Current and potential therapeutic strategies for mucopolysaccharidoses. J. Clin. Pharm. Ther. 2014, 39, 215-224. [CrossRef]

222. Marin, L.; Gutierrez-Solana, L.; Fernandez, A. Hunter syndrome: Resolution of extensive typical skin lesions after 9 months of enzyme replacement therapy with idursulfase. Pediatr. Dermatol. 2012, 29, 369-371. [CrossRef]

223. Ito, K.; Ochiai, T.; Suzuki, H.; Chin, M.; Shichino, H.; Mugishima, H. The effect of haematopoietic stem cell transplant on papules with "pebbly" appearance in Hunter's syndrome. Br. J. Dermatol. 2004, 151, 207-211. [CrossRef] [PubMed]

224. Vellodi, A.; Young, E.; Cooper, A.; Lidchi, V.; Winchester, B.; Wraith, J.E. Long-term follow-up following bone marrow transplantation for Hunter disease. J. Inherit. Metab. Dis. 1999, 22, 638-648. [CrossRef]

225. Tanjuakio, J.; Suzuki, Y.; Patel, P.; Yasuda, E.; Tanaka, A.; Yabe, H.; Mason, R.W.; Montaño, A.M.; Orii, K.E.; Orii, K.O.; et al. Activities of Daily Living in patients with Hunter syndrome: Impact of enzyme replacement therapy and hematopoietic stem cell transplantation. Mol. Genet. Metab. 2015, 114, 161-169. [CrossRef]

226. Hobbs, J.; Hugh-Jones, K.; Barrett, A.; Byrom, N.; James, D.C.O.; Lucas, C.F. Reversal of clinical features of Hurler's disease and biochemical improvement after treatment by bone-marrow transplantation. Lancet 1981, 2, 709-712. [CrossRef]

227. Peters, C.; Balthazor, M.; Shapiro, E.G.; King, R.J.; Kollman, C.; Hegland, J.D.; Henslee-Downey, J.; Trigg, M.E.; Cowan, M.J.; Sanders, J.; et al. Outcome of unrelated donor bone marrow transplantation in 40 children with Hurler syndrome. Blood 1996, 87, 4894-4902. [CrossRef] [PubMed]

228. Muenzer, J. Overview of the mucopolysaccharidoses. Rheumatology 2011, 50, 4-12. [CrossRef] [PubMed]

229. Araya, K.; Sakai, N.; Mohri, I.; Kagitani-Shimono, K.; Okinaga, T.; Hashii, Y.; Ohta, H.; Nakamichi, I.; Aozasa, K.; Taniike, M.; et al. Localized donor cells in brain of a Hunter disease patient after cord blood stem cell transplantation. Mol. Genet. Metab. 2009, 98, 255-263. [CrossRef] [PubMed]

230. Vellodi, A. Bone marrow transplantation for lysosomal storage disorders. Expert Rev. Endocrinol. Metab. 2006, 1, 425-438. [CrossRef]

231. Taylor, M.; Khan, S.; Stapleton, M.; Wang, J.; Chen, J.; Wynn, R.; Yabe, H.; Chinen, Y.; Boelens, J.J.; Robert, W.; et al. Hematopoietic stem cell transplantation for mucopolysaccharidoses; past, present, and future Madeleine. Biol. Blood Marrow Transpl. 2019, 25, 226-246. [CrossRef]

232. Garcia, A.R.; DaCosta, J.M.; Pan, J.; Muenzer, J.; Lamsa, J.C. Preclinical dose ranging studies for enzyme replacement therapy with idursulfase in a knock-out mouse model of MPS II. Mol. Genet. Metab. 2007, 91, 183-190. [CrossRef]

233. Laoharawee, K.; Podetz-Pedersen, K.M.; Nguyen, T.T.; Evenstar, L.B.; Kitto, K.F.; Nan, Z.; Fairbanks, C.A.; Low, W.C.; Kozarsky, K.F.; McIvor, R.S. Prevention of Neurocognitive Deficiency in Mucopolysaccharidosis Type II Mice by Central Nervous SystemDirected, AAV9-Mediated Iduronate Sulfatase Gene Transfer. Hum. Gene Ther. 2017, 28, 626-638. [CrossRef] [PubMed]

234. Polito, V.A.; Cosma, M.P. IDS Crossing of the Blood-Brain Barrier Corrects CNS Defects in MPSII Mice. Am. J. Hum. Genet. 2009, 85, 296-301. [CrossRef]

235. Ahn, S.Y.; Chang, Y.S.; Sung, D.K.; Ko, A.R.; Kim, C.H.; Yoo, D.K.; Lim, K.H.; Sohn, Y.B.; Jin, D.K.; Park, W.S. High-dose enzyme replacement therapy attenuates cerebroventriculomegaly in a mouse model of mucopolysaccharidosis type II. J. Hum. Genet. 2013, 58, 728-733. [CrossRef]

236. Wada, M.; Shimada, Y.; Iizuka, S.; Ishii, N.; Hiraki, H.; Tachibana, T.; Maeda, K.; Saito, M.; Arakawa, S.; Ishimoto, T.; et al. Ex Vivo Gene Therapy Treats Bone Complications of Mucopolysaccharidosis Type II Mouse Models through Bone Remodeling Reactivation. Mol. Ther. Methods Clin. Dev. 2020, 19, 261-274. [CrossRef]

237. Froissart, R.; Da Silva, I.M.; Maire, I. Mucopolysaccharidosis type II: An update on mutation spectrum. Acta Paediatr. Int. J. Paediatr. 2007, 96, 71-77. [CrossRef] 
238. Dvorakova, L.; Vlaskova, H.; Sarajlija, A.; Ramadza, D.; Poupetova, H.; Hruba, E.; Hlavata, A.; Bzuduch, V.; Peskova, K.; Storkanova, G.; et al. Genotype-phenotype correlation in 44 Czech, Slovak, Croatian and Serbian patients with mucopolysaccharidosis type II. Clin. Genet. 2017, 91, 787-796. [CrossRef] [PubMed]

239. Semyachkina, A.N.; Voskoboeva, E.Y.; Nikolaeva, E.A.; Zakharova, E.Y. Analysis of long-term observations of the large group of Russian patients with Hunter syndrome (mucopolysaccharidosis type II). BMC Med. Genomics 2021, 14, 71. [CrossRef]

240. Alcántara-Ortigoza, M.A.; García-de Teresa, B.; González-del Angel, A.; Berumen, J.; Guardado-Estrada, M.; FernándezHernández, L.; Navarrete-Martínez, J.I.; Maza-Morales, M.; Rius-Domínguez, R. Wide allelic heterogeneity with predominance of large IDS gene complex rearrangements in a sample of Mexican patients with Hunter syndrome. Clin. Genet. 2016, 89, 574-583. [CrossRef] [PubMed]

241. Brusius-Facchin, A.C.; Schwartz, I.V.D.; Zimmer, C.; Ribeiro, M.G.; Acosta, A.X.; Horovitz, D.; Monlleó, I.L.; Fontes, M.I.B.; Fett-Conte, A.; Sobrinho, R.P.O.; et al. Mucopolysaccharidosis type II: Identification of 30 novel mutations among Latin American patients. Mol. Genet. Metab. 2014, 111, 133-138. [CrossRef]

242. Kosuga, M.; Mashima, R.; Hirakiyama, A.; Fuji, N.; Kumagai, T.; Seo, J.H.; Nikaido, M.; Saito, S.; Ohno, K.; Sakuraba, H.; et al. Molecular diagnosis of 65 families with mucopolysaccharidosis type II (Hunter syndrome) characterized by 16 novel mutations in the IDS gene: Genetic, pathological, and structural studies on iduronate-2-sulfatase. Mol. Genet. Metab. 2016, 118, 190-197. [CrossRef] [PubMed]

243. Alkhzouz, C.; Lazea, C.; Bucerzan, S.; Nascu, I.; Kiss, E.; Denes, C.; Grigorescu-Sido, P. Clinical and Genetic Characteristics of Romanian Patients with Mucopolysaccharidosis Type II. JIMD Rep. 2017, 33, 19-25. [CrossRef] [PubMed]

244. Calias, P.; Papisov, M.; Pan, J.; Savioli, N.; Belov, V.; Huang, Y.; Lotterhand, J.; Alessandrini, M.; Liu, N.; Fischman, A.J.; et al. CNS penetration of intrathecal-lumbar idursulfase in the monkey, dog and mouse: Implications for neurological outcomes of lysosomal storage disorder. PLoS ONE 2012, 7, e30341. [CrossRef]

245. Sohn, Y.B.; Ko, A.R.; Seong, M.R.; Lee, S.; Kim, M.R.; Cho, S.Y.; Kim, J.S.; Sakaguchi, M.; Nakazawa, T.; Kosuga, M.; et al. The efficacy of intracerebroventricular idursulfase-beta enzyme replacement therapy in mucopolysaccharidosis II murine model: Heparan sulfate in cerebrospinal fluid as a clinical biomarker of neuropathology. J. Inherit. Metab. Dis. 2018, 41, 1235-1246. [CrossRef]

246. Sohn, Y.B.; Lee, J.; Cho, S.Y.; Kim, S.J.; Ko, A.R.; Nam, M.H.; Jin, D.K. Improvement of CNS Defects Via Continuous Intrathecal Enzyme Replacement by Osmotic Pump in Mucopolysaccharidosis Type II Mice. Am. J. Med. Genet. Part A 2013, 161, 1036-1043. [CrossRef]

247. Muenzer, J.; Hendriksz, C.J.; Fan, Z.; Vijayaraghavan, S.; Perry, V.; Santra, S.; Solanki, G.A.; Mascelli, M.A.; Pan, L.; Wang, N.; et al. A phase I/II study of intrathecal idursulfase-IT in children with severe mucopolysaccharidosis II. Genet. Med. 2016, 18, 73-81. [CrossRef] [PubMed]

248. Muenzer, J.; Hendriksz, C.J.; Stein, M.B.; Fan, Z.; Kearney, S.; Horton, J.; Vijayaraghavan, S.; Santra, S.; Solanki, G.A.; Pan, L.; et al. A long-term extension study evaluating intrathecal idursulfase-IT in children with Hunter syndrome and cognitive impairment. Mol. Genet. Metab. 2016, 99-100. [CrossRef]

249. Giugliani, R.; Dalla Corte, A.; Poswar, F.; Vanzella, C.; Horovitz, D.; Riegel, M.; Baldo, G.; Vairo, F. Intrathecal/Intracerebroventricular enzyme replacement therapy for the mucopolysaccharidoses: Efficacy, safety, and prospects. Expert Opin. Orphan Drugs 2018, 6, 403-411. [CrossRef]

250. Seo, J.H.; Kosuga, M.; Hamazaki, T.; Shintaku, H.; Okuyama, T. Impact of intracerebroventricular enzyme replacement therapy in patients with neuronopathic mucopolysaccharidosis type II. Mol. Ther. Methods Clin. Dev. 2021, 21, 67-75. [CrossRef] [PubMed]

251. Sonoda, H.; Morimoto, H.; Yoden, E.; Koshimura, Y.; Kinoshita, M.; Golovina, G.; Takagi, H.; Yamamoto, R.; Minami, K.; Mizoguchi, A.; et al. A Blood-Brain-Barrier-Penetrating Anti-human Transferrin Receptor Antibody Fusion Protein for Neuronopathic Mucopolysaccharidosis II. Mol. Ther. 2018, 26, 1366-1374. [CrossRef] [PubMed]

252. Zhou, Q.H.; Boado, R.J.; Lu, J.Z.; Hui, E.K.W.; Pardridge, W.M. Brain-penetrating IgG-iduronate 2-sulfatase fusion protein for the mouse. Drug Metab. Dispos. 2012, 40, 329-335. [CrossRef] [PubMed]

253. Morimoto, H.; Kida, S.; Yoden, E.; Kinoshita, M.; Tanaka, N.; Yamamoto, R.; Koshimura, Y.; Takagi, H.; Takahashi, K.; Hirato, T.; et al. Clearance of heparan sulfate in the brain prevents neurodegeneration and neurocognitive impairment in MPS II mice. Mol. Ther. 2021, 29, 1853-1861. [CrossRef] [PubMed]

254. Okuyama, T.; Eto, Y.; Sakai, N.; Minami, K.; Yamamoto, T.; Sonoda, H.; Yamaoka, M.; Tachibana, K.; Hirato, T.; Sato, Y. Iduronate2-Sulfatase with Anti-human Transferrin Receptor Antibody for Neuropathic Mucopolysaccharidosis II: A Phase 1/2 Trial. Mol. Ther. 2019, 27, 456-464. [CrossRef]

255. Okuyama, T.; Eto, Y.; Sakai, N.; Nakamura, K.; Yamamoto, T.; Yamaoka, M.; Ikeda, T.; So, S.; Tanizawa, K.; Sonoda, H.; et al. A Phase 2/3 Trial of Pabinafusp Alfa, IDS Fused with Anti-Human Transferrin Receptor Antibody, Targeting Neurodegeneration in MPS-II. Mol. Ther. 2021, 29, 671-679. [CrossRef] [PubMed]

256. Giugliani, R.; Martins, A.M.; So, S.; Yamamoto, T.; Yamaoka, M.; Ikeda, T.; Tanizawa, K.; Sonoda, H.; Schmidt, M.; Sato, Y. Iduronate-2-sulfatase fused with anti-human transferrin receptor antibody, pabinafusp alfa, for treatment of neuronopathic and non-neuronopathic mucopolysaccharidosis II: Report of a phase 2 trial in Brazil. Mol. Ther. 2021, 29, 2378-2386. [CrossRef]

257. Boado, R.J.; Hui, E.K.-W.; Lu, J.Z.; Pardridge, W.M. Insulin Receptor Antibody-Iduronate 2-Sulfatase Fusion Protein: Pharmacokinetics, Anti-Drug Antibody, and Safety Pharmacology in Rhesus Monkeys. Biotechnol. Bioeng. 2014, 111, $2317-2325$. [CrossRef] 
258. Boado, R.J.; Hui, E.K.W.; Lu, J.Z.; Sumbria, R.K.; Pardridge, W.M. Blood-brain barrier molecular trojan horse enables imaging of brain uptake of radioiodinated recombinant protein in the rhesus monkey. Bioconjug. Chem. 2013, 24, 1741-1749. [CrossRef]

259. Foust, K.; Nurre, E.; Montgomery, C.; Hernandez, A.; Chan, C.; Kaspar, B. Intravascular AAV9 preferentially targets neonatalneurons and adult-astrocytes in CNS. Nat. Biotechnol. 2009, 27, 59-65. [CrossRef] [PubMed]

260. Fu, H.; Dirosario, J.; Killedar, S.; Zaraspe, K.; McCarty, D.M. Correction of neurological disease of mucopolysaccharidosis IIIB in adult mice by rAAV9 trans-blood-brain barrier gene delivery. Mol. Ther. 2011, 19, 1025-1033. [CrossRef]

261. Ruzo, A.; Marcó, S.; García, M.; Villacampa, P.; Ribera, A.; Ayuso, E.; Maggioni, L.; Mingozzi, F.; Haurigot, V.; Bosch, F. Correction of pathological accumulation of glycosaminoglycans in central nervous system and peripheral tissues of MPSIIIA mice through systemic AAV9 gene transfer. Hum. Gene Ther. 2012, 23, 1237-1246. [CrossRef]

262. Sharma, R.; Anguela, X.M.; Doyon, Y.; Wechsler, T.; DeKelver, R.C.; Sproul, S.; Paschon, D.E.; Miller, J.C.; Davidson, R.J.; Shivak, D.; et al. In vivo genome editing of the albumin locus as a platform for protein replacement therapy. Blood 2015, 126, 1777-1784. [CrossRef] [PubMed]

263. Sheridan, C. Sangamo's landmark genome editing trial gets mixed reception. Nat. Biotechnol. 2018, 36, 907-908. [CrossRef] [PubMed]

264. Krivit, W.; Sung, J.; Shapiro, E.G.; Lockman, L.A. Microglia: The effector cell for reconstitution of the central nervous system following bone marrow transplantation for lysosomal and peroxisomal storage diseases. Cell Transpl. 1995, 4, 385-392. [CrossRef]

265. Capotondo, A.; Milazzo, R.; Politi, L.S.; Quattrini, A.; Palini, A.; Plati, T.; Merella, S.; Nonis, A.; Di Serio, C.; Montini, E.; et al Brain conditioning is instrumental for successful microglia reconstitution following hematopoietic stem cell transplantation. Proc. Natl. Acad. Sci. USA 2012, 109, 15018-15023. [CrossRef] [PubMed]

266. Yeager, A.M.; Shinohara, M.; Shinn, C. Hematopoietic cell transplantation after administration of high-dose busulfan in murine globoid cell leukodystrophy (the twitcher mouse). Pediatr. Res. 1991, 29, 302-305. [CrossRef] [PubMed]

267. Kennedy, D.W.; Abkowitz, J.L. Kinetics of central nervous system microglial and macrophage engraftment: Analysis using a transgenic bone marrow transplantation model. Blood 1997, 90, 986-993. [CrossRef]

268. Saha, A.; Buntz, S.; Scotland, P.; Xu, L.; Noeldner, P.; Patel, S.; Wollish, A.; Gunaratne, A.; Gentry, T.; Troy, J.; et al. A cord blood monocyte-derived cell therapy product accelerates brain remyelination. JCI Insight 2016, 1, e86667. [CrossRef] [PubMed]

269. Kurtzberg, J.; Buntz, S.; Gentry, T.; Noeldner, P.; Ozamiz, A.; Rusche, B.; Stroms, R.; Wollish, A.; Wenger, D.; Balber, A. Preclinical characterization of DUOC-01, a cell therapy product derived from banked umbilical cord blood for use as an adjuvant to umbilical cord blood transplantation for treatment of inherited metabolic diseases. Cytotherapy 2015, 17, 803-815. [CrossRef] [PubMed] 